\title{
The geology and hydrogeology of buried bedrock valley aquifers on Cape Breton Island, Nova Scotia: an overview
}

\author{
FRED BAECHLER \\ Exp Services Inc., 301 Alexandra Street, Suite A, Sydney, Nova Scotia B1S 2E8, Canada \\ $<$ fred.baechler@exp.com>
}

Date received: 15 June 2016 Date accepted 12 June 2017

\begin{abstract}
Buried bedrock valley aquifers are common across Canada, where multiple glaciations have buried both pre-glacial and Pleistocene valleys. These aquifers are becoming increasingly important as a supply of potable groundwater, for supporting aquatic habitat, and as part of strategies in adapting to a changing climate. However, in Canada, there are considerable knowledge gaps at national, regional, and local scales, such that many buried bedrock valleys remain unidentified or underexplored. Cape Breton Island provides a hydrogeological view into the roots of an ancient mountain range, now exhumed, glaciated, deglaciated, and tectonically inactive. Since the Cretaceous, a variety of geological processes have formed several buried bedrock valley aquifers over the island. These aquifers are important in providing municipal and commercial groundwater supplies, controlling mine dewatering, protection of salmonids, design and monitoring of waste disposal sites, and geotechnical investigations for infrastructure design. Of 150 sites assessed, 61\% provided evidence of buried aquifers comprising unconsolidated sand and gravel of Cretaceous, Pleistocene, and Holocene ages. These sites provided the basis for five conceptual, 3-D hydrogeological block models. Three hydrogeological case studies provided further insight into the functioning of two of these models. Future studies should identify and characterize aquifers in high demand areas and/or those that support important riverine ecosystems. Research should focus on aquifer properties, groundwater-stream interaction, and the impact of changing climate with sea-level rise.
\end{abstract}

\begin{abstract}
RÉSUMÉ
Les vallées aquifères enfouies dans le substrat rocheux sont répandues partout au Canada, où plusieurs glaciations ont enfoui à la fois des vallées préglaciaires et des vallées du Pléistocène. Ces aquifères deviennent de plus en plus importants comme sources d'alimentation en eau souterraine potable, pour le soutien de l'habitat aquatique et dans le cadre des stratégies d'adaptation à un climat changeant. Au Canada, toutefois, des lacunes considérables subsistent dans les connaissances quon en a à l'échelle nationale, régionale et locale, nombre de vallées n'ayant pas encore été localisées ou demeurant sous-explorées. Lîle du Cap Breton présente un aperçu hydrogéologique des racines d'une ancienne chaîne de montagnes, maintenant exhumée, érodée par la glaciation et tectoniquement inactive. Depuis le Crétacé, divers processus géologiques ont formé plusieurs vallées aquifères
\end{abstract}


enfouies dans le substrat rocheux sur l'île. Ces aquifères sont importants, car ils représentent des réserves deau souterraines municipales et commerciales, permettent le contrôle de l'assèchement des puits de mines, assurent la protection des salmonidés et servent à la conception et à la surveillance des sites d’enfouissement ainsi qu’aux études géotechniques réalisées pour la conception des infrastructures. Soixante et un pour cent des 150 emplacements évalués ont fourni une preuve d'existence d’aquifères enfouis constitués de sable et de gravier non consolidés remontant au Crétacé, au Pléistocène et à l'Holocène. Ces emplacements ont servi de fondement à cinq modèles conceptuels tridimensionnels de blocs hydrogéologiques. Trois études de cas hydrogéologiques ont permis de comprendre plus en détail le fonctionnement de deux des modèles. Les études futures devraient tenter avant tout de localiser et caractériser les aquifères dans les secteurs à forte demande ou ceux soutenant des écosystèmes riverains importants. Les recherches devraient être axées sur les propriétés des aquifères, l'interaction entre l'eau souterraine et les cours d'eau, ainsi que l'incidence des changements climatiques et de la hausse du niveau de la mer.

[Traduit par la redaction]

\section{INTRODUCTION}

Buried bedrock valley (BBV) aquifers are common across the formerly glaciated terrain of North America (Grasby et al. 2014) and Europe (King 1980), created by multiple glaciations, and formed in pre-glacial and Pleistocene valleys (Upson and Spencer 1964; Denne et al. 1984; Faunt et al. 2010; Pugin et al. 2014; Russell et al. 2004; Seyoum and Eckstein 2014). This type of aquifer is commonly high yielding and readily recharged by rapid infiltration from precipitation and permeable streams. As such it forms an important supplier of potable groundwater to many cities in North America and Europe, but it is also highly susceptible to contamination (Springer and Blair 1992). The importance of channel-aquifer interactions is recognized in supporting benthic invertebrates and salmonids, as well as in controlling large-scale hyporheic floodplain corridors (Stanford and Ward 1993).

Recognition of the importance of BBV aquifers in Canada prompted their mapping in Alberta (Beaney and Shaw 2000; Morgan et al. 2008; Cummings et al. 2012; Atkinson et al. 2013), Saskatchewan (van der Kamp and Maathuis 2012), the Canadian Prairies (Pugin et al. 2014), Ontario (Flint and Lolcama 1986; Kor et al. 1991; Brennand and Shaw 1994; Russell et al. 2001; Meyer and Eyles 2007; Cole et al. 2009; Gao 2011), British Columbia (Hickin et al. 2008), the Northwest Territories (Rampton 2000), and eastern Canada (Randall et al. 1988; Butler et al. 2004; Tawil and Harriman 2001; Rivard et al. 2008).

Cape Breton Island forms the northeastern part of the Province of Nova Scotia, along the Atlantic seaboard of Canada (Fig.1a). It encompasses an area of approximately $11700 \mathrm{~km}^{2}$ and faces the Atlantic Ocean to the east and the Gulf of St. Lawrence to the north and west (Fig.1b). Although BBV aquifers have not been comprehensively mapped on Cape Breton Island, the author's experience indicates that they have played a role in: (1) developing potable groundwater supplies for towns and commercial ventures, (2) providing irrigation waters for golf courses, (3) design of disposal sites, (4) regional water resource evaluations, (5) investigating groundwater stream interaction as it influences salmonid habitat, (6) environmental impact assessments, (7) predicting and controlling inflows to mines, and (8) geotechnical investigations for transportation corridors, infrastructure, and dams. The valleys they underlie have, for over 100 years, provided lands for farming, aggregate extraction, major traffic corridors, and suburbanization.

This paper is the fifth in a series that describes what is presently understood about Cape Breton Island's fresh water resources to aid in their effective management. A review of Cape Breton Island's paleohydrology, outlining the timing and formation of BBV aquifers, a description of the present hydrological setting of the island, and a description of known BBV aquifers, including three detailed hydrogeological case studies are presented. Much of the data provided in the case studies comes from over 130 consultant studies which, for the most part, constitute privately funded work carried out for a variety of municipal, industrial, mining, transportation, and commercial clients over the past 40 years. While the associated reports are referenced, they have been submitted to clients, and in some instances to Provincial regulatory agencies in support of permit applications. This "grey' literature is not available in peer-reviewed journals, nor for the most part available to the reader. Nevertheless, the importance of this applied research is becoming recognized in establishing a base for groundwater knowledge management (Holysh and Gerber 2014).

\section{GEOLOGY AND PALEOHYDROLOGY}

Cape Breton Island's ca. $1 \mathrm{Ga}$ geological history created a complex lithological and structural terrain through plate collision, mountain building, regional scale faulting, sedimentary basin formation, karstification, the opening of the Atlantic Ocean, prolonged exhumation, multiple glaciations, and variable sea levels, which is now molded by a maritime climate. Exhumation and glaciation over approximately $140 \mathrm{Ma}$ since the Early Cretaceous is of particular relevance to the formation of BBV aquifers. 
(b)

(a)
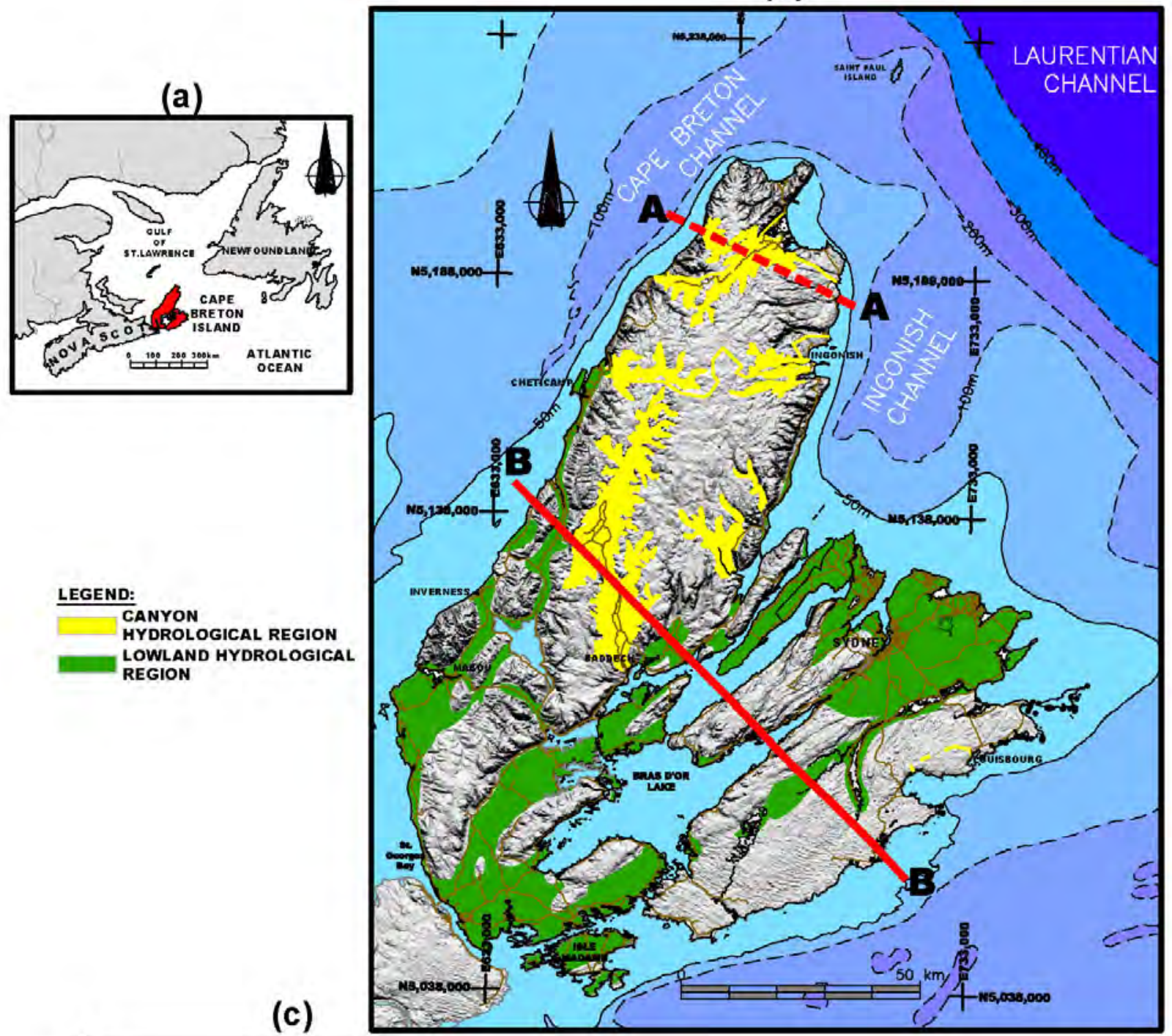

(c)

GANYON LOWLAND HYDROLOGICAL REGION
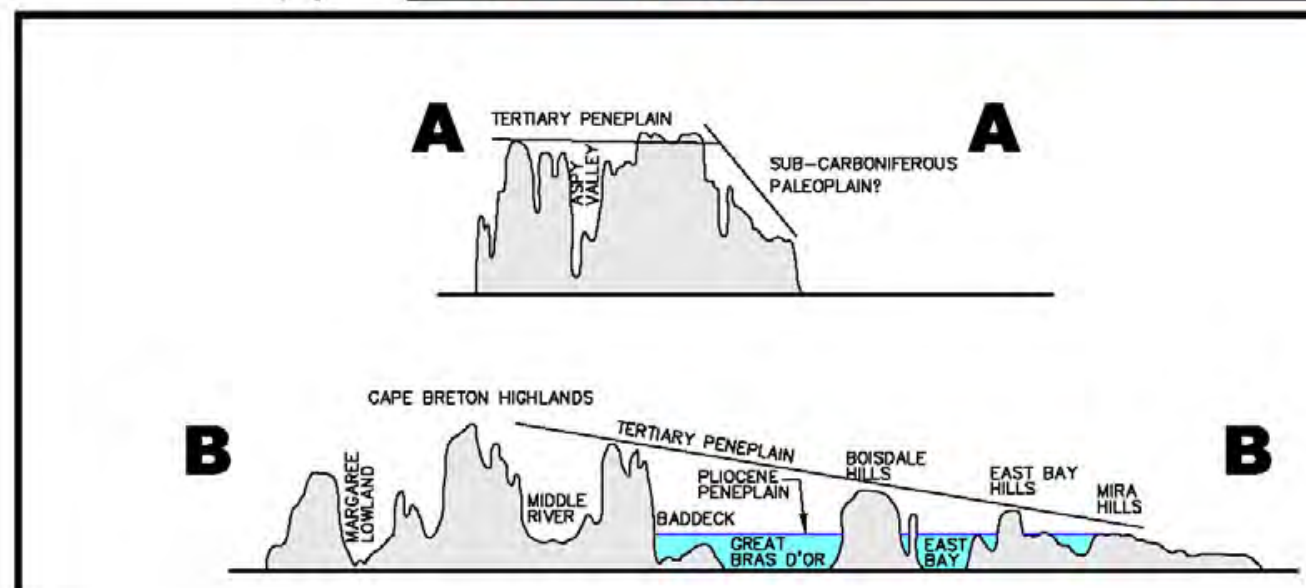

Figure 1. Regional location map (Fig. 1a), delineating Lowland and Canyon Hydrological Regions and adjacent bathymetric contours (Fig. 1b), as well as select topographic profiles for ancient peneplains (Fig. 1c). 
Mesozoic erosion created a broad, lowland peneplain of the Appalachian mountain chain within which Cape Breton Island is located (Pascucci et al. 2000). The deposition of Cretaceous sediments in fault-bound basins and karstified paleosurfaces (Stea and Pullan 2001; Falcon-Lang et al. 2007) indicates that most of the present topography is a Mesozoic structural remnant and provides for one type of BBV aquifer on Cape Breton Island.

During the Cenozoic, sea level declined at times to at least $200 \mathrm{~m}$ below present level and the Mesozoic peneplain was uplifted and tilted to the east (Nova Scotia Museum 1997). During the subsequent erosional cycle, resistant crystalline basement rocks became more prominent on the landscape, while the softer sedimentary rocks created the lowlands. Grant (1994) noted that this exhumation provided the present island landscape with two major planation surfaces (Fig. 1c). The Paleogene/Neogene (Tertiary) peneplain slopes southeast and maintains its identity as a geomorphic feature across the entire island from the western Cape Breton highlands at over $500 \mathrm{~m}$ to the east coast at $30 \mathrm{~m}$. It is incised by a system of "V"-shaped gorges and "U"-shaped canyons that likely predate the last glacial maximum (Grant 1994). A younger Pliocene peneplain comprises a network of interconnected lowlands ranging from 10 to $200 \mathrm{~m}$ elevation, developed mainly on Carboniferous sedimentary rocks (Grant 1994).

Approximately 16 major glacial periods have been estimated for Cape Breton Island over the past ca. two million years (Stea et al. 2003), affording ample opportunity for further development of BBV aquifers. The island's Wisconsinan glacial history is complex and under repeated refinement. It comprised interaction between the Laurentide Ice Sheet (LIS) and an independent Appalachian Ice Complex (AIC). The interplay of sea-level change, icesheet stability, and isostatic/eustatic variations within a lithologically and topographically diverse terrain facilitated creation of BBV aquifers. The glacial history pertinent to BBV aquifer formation is summarized below from Grant (1994), Stea et al. (1998, 2003, 2006), Shaw et al. (2002), and Shaw (2005).

Initially an ice cap formed over the Cape Breton Highlands, followed by a northeastward flow from the AIC over the southern lowlands ( 75 to $40 \mathrm{ka}$ ), during which time sea level was placed at approximately -100 m (Grant 1994). From 22 to $15 \mathrm{ka}$ a dominant ice sheet moved southeastward over the Island covering the highlands and extending onto the continental shelf. By $13.5 \mathrm{ka}$ the LIS ice stream retreat in the Laurentian Channel caused re-organization to local centers including the Bras d'Or, Highlands, and Gulf of St. Lawrence (Fig. 2a). The latter ice sheet intermittently blocked westward meltwater drainage creating six proglacial lakes with interconnected, north-draining, meltwater spillways to Lake Margaree, and then through the Cheticamp meltwater channel to the ocean (Figs. 2a, 3). The period 12.5 to $10 \mathrm{ka} \mathrm{saw}$ both retreat and reactivation of the Bras d'Or and Highlands ice caps, creating outlet glaciers and spillway channels down major Canyon valleys such as the Aspy, Clyburn, Ingonish, Middle, Margaree, and Cheticamp. Localized cirque glaciers were developed in the northern highland peneplain. Lobes of the Bras d'Or ice centre extended north through St Anns Bay, the Great Bras d'Or, St. Andrews Channel, East Bay, and the Mira River after 10,300 BP. Blockage by southern ice lobes and Gulf ice created proglacial lakes Dawson and Bell (Fig. 2b), as well as the Moran-Hawthorne basin and Judique coastal plain (Fig. 2b). At 9 ka the emergent areas reached their greatest aerial extent with a sea level of approximately $-50 \mathrm{~m}$. This was followed by sea level rise which, after 6000 $\mathrm{BP}$, resulted in inundation of drainage systems (Shaw et al. 2002 ) and presently continues to rise at $0.36 \mathrm{~m} / 100$ years (Grant 1994). Therefore, present-day streams represent the upper headwaters of large drainage systems whose channels and valleys now extend offshore.

The formation of BBV aquifers is a topic of debate (Gray 2001; Boulton et al. 2007, 2009; Creyts and Schoof 2009; Kehew et al. 2012; Van der Vegt et al. 2012). During glacial advance the former subaerial groundwater flow systems are combined into a single, confined, sub-glacial system, creating flow from the interior to the ice margin (Lemieux et al. 2008; Kehew et al. 2012). The sub-glacial drainage system integrates channels and groundwater flow (Person et al. 2007; Kehew et al. 2012; Atkinson et al. 2013) through $\mathrm{R}$ channels, where meltwaters erode upward into the ice forming eskers, as well as $\mathrm{N}$ channels incised downward into poorly consolidated strata. During glacial retreat proglacial meltwater channels downstream of the ice terminus can infill existing valleys. The sedimentological processes active within these channels, coupled with localized glacial overriding and proglacial lakes, can create a wide variety of facies within the BBV aquifers (Upson and Spencer 1964; Kehew and Boettger 1986; Sharpe 1988; Broster and Pupek 2001; Rivard et al. 2008; Cummings et al. 2012). This complexity can create longitudinal and transverse hydraulic barriers and contrasting hydraulic responses (Kehew and Boettger 1986; Shaver and Pusc 1992; Russell et al. 2004; Weissmann et al. 2004; Van der Kamp and Maathuis 2012).

The three types of Quaternary aquifers, as defined by Wei et al. (2014), that are the most relevant for Cape Breton Island are: Type 1 (aquifers in unconfined fluvial or glaciofluvial sands and gravels), Type 3 (aquifers which occur in alluvial or colluvial deposits positioned near the base of mountain slopes), and Type 4 (pre-glacial or glacialorigin aquifers that occur at the surface or are buried under till or glaciolacustine deposits).

Regional surficial geological mapping of Cape Breton Island by Grant (1994) and Stea et al. (2006) identified glaciofluvial and ice-contact sands and gravels created by Wisconsinan glaciation, covering approximately $6.5 \%$ of the Island (Fig. 3). These deposits are principally associated 
(a)

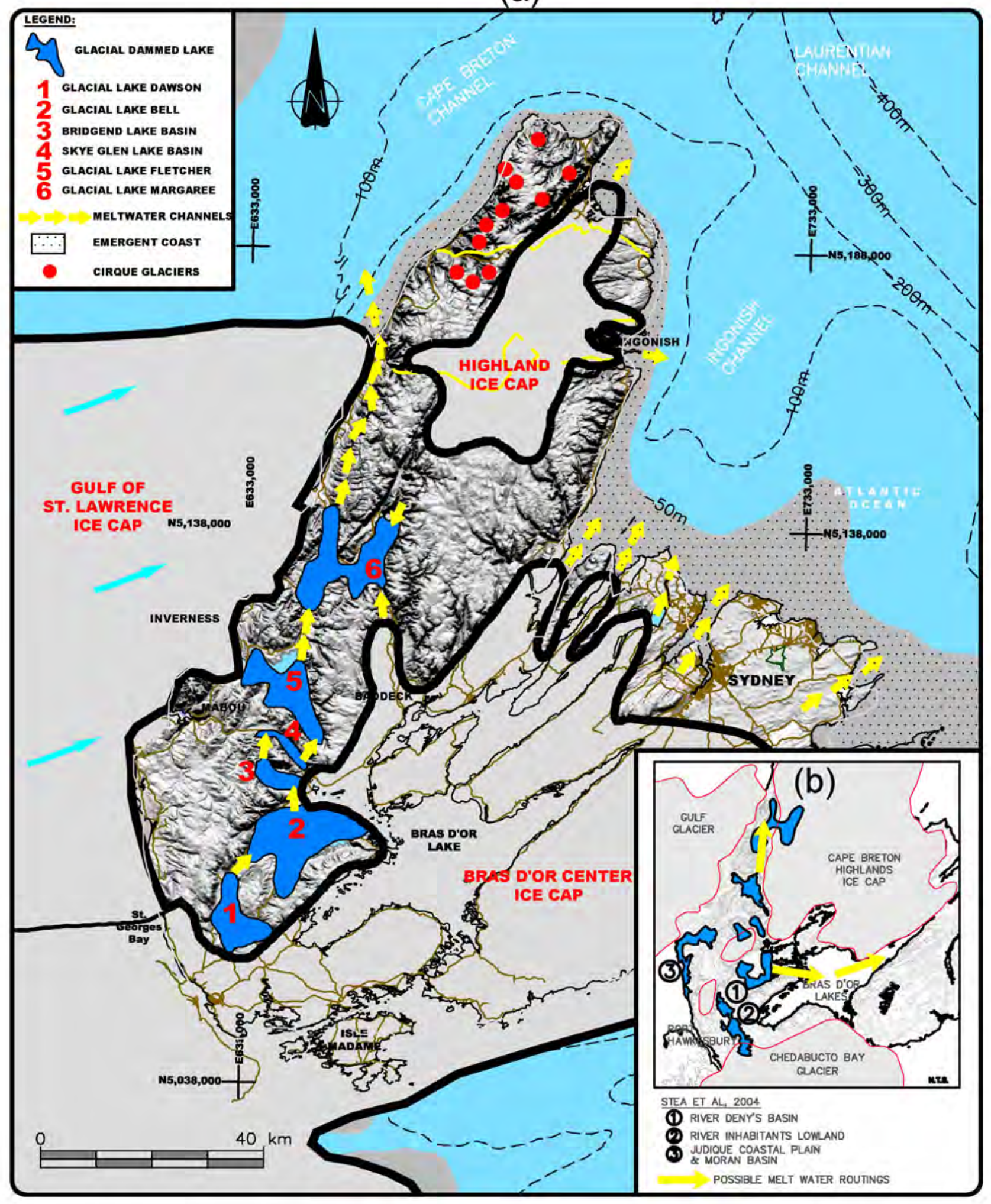

Figure 2. Phases of Wisconsinan de-glaciation (Figs. 2a, 2b) of Cape Breton Island combined from Grant (1994) and Stea et al. (2004). 


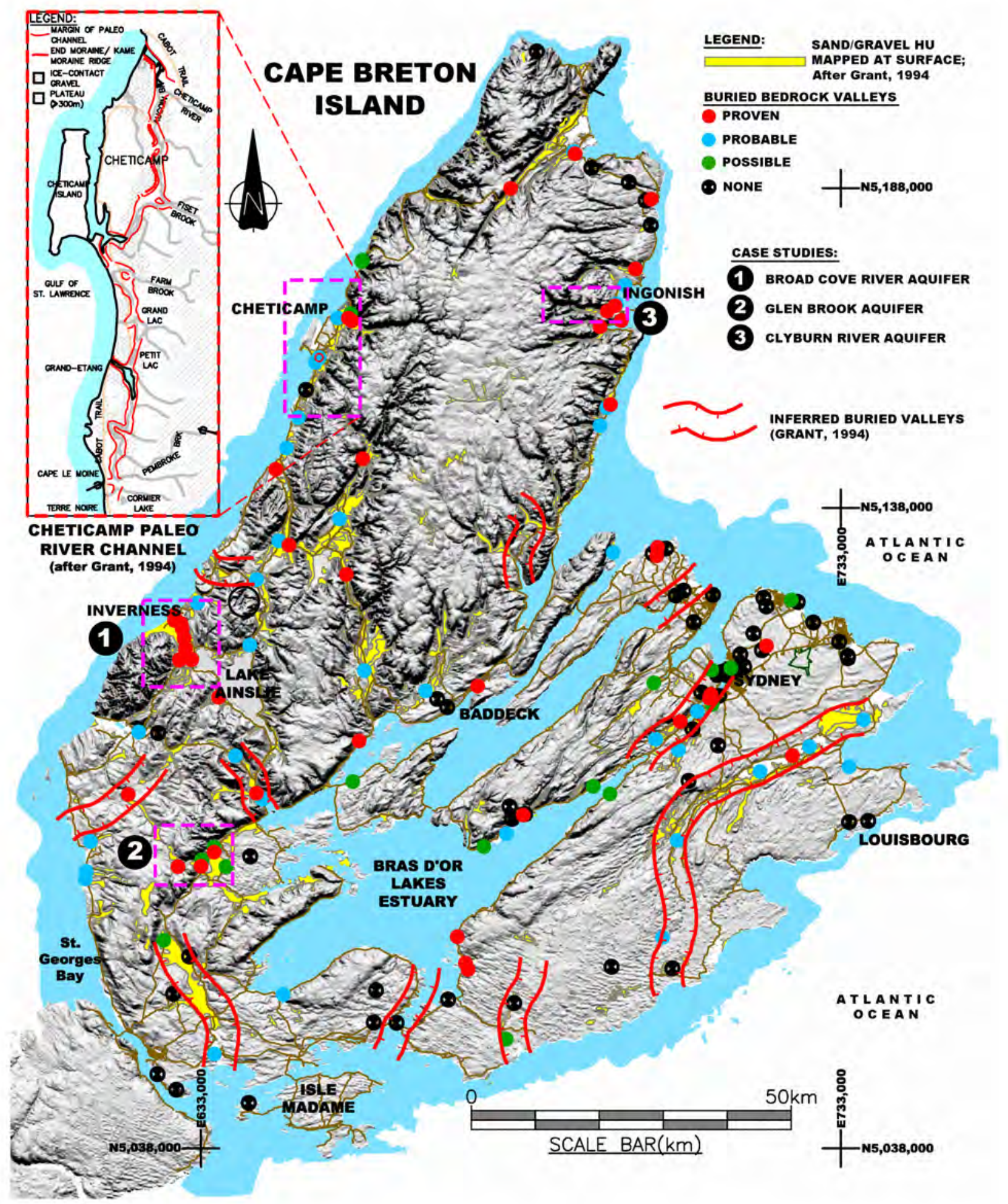

Figure 3. Location of proven, probable and possible BBV aquifers in Cape Breton Island based on reports and field data. The locations of the three case studies described in the text are also outlined. 
with large outwash plains in the Margaree, Baddeck, Middle, Mira, Aspy, Denys, and Inhabitants river valleys. Grant (1994) inferred the potential presence of 11 major buried valleys (Fig. 3) over the island. He also noted that the number of buried valleys, which can be seen and reasonably inferred in the heavily drift-covered areas of the island, point to the likelihood of others being found. Stea et al. (2006) identified localized sand and gravel in deep, drift-covered, lowland basins, confined between glacial tills and lacustrine clays. Submarine extensions of these features occur on the adjacent continental shelf and beneath the Bras d'Or Lake (Shaw 2005; Shaw et al. 2006, 2009; MacRae and Christians 2013).

\section{MODERN HYDROLOGICAL SETTING}

Cape Breton Island has a temperate, humid, continental climate, with a 30-year normal (1981 to 2010) annual precipitation of $1517 \mathrm{~mm}$, and mean annual temperature of $5.9^{\circ} \mathrm{C}$. These conditions provide for an estimated annual water surplus and deficit using the method of Thornthwaite (1948) of 987 and $21 \mathrm{~mm}$, respectively. Sharpe et al. (2014) positioned Cape Breton Island nationally in both the Appalachian and Maritimes Basin hydrogeological regions. Baechler and Baechler (2009) developed a regional classification, which mapped six hydrological regions over the island by defining areas with characteristic types, numbers and orientations of hydrostratigraphic units (HUs), coupled with climate, topographic relief, and forest cover.

The Lowland and Canyon regions (Fig 1b) are relevant to the discussion of BBV aquifers. Representative 3-D block conceptual models (Figs. 4, 5) combine the approaches outlined by LeGrand and Rosen (2000), Bredhoeft (2005), Hill (2006), and Savard et al. (2014), which utilize generalizations and inferences with existing geological information to draw conclusions from imprecise and incomplete information. The models focus on the active groundwater flow system down to approximately $200 \mathrm{~m}$ depth, as defined by Mayo et al. (2003). The models are designed to meet the three goals of simplicity, refutability, and transparency. They should not be regarded as immutable and surprises will be inevitable as new concepts require refinements or a complete paradigm shift.

The Lowland Hydrological Region (Fig. 1b) covers approximately $24 \%$ of Cape Breton Island. It comprises four hydrological districts developed over the Pliocene peneplain, including:

(1) The Sedimentary Plain and Homoclinal Flank Districts (Fig. 4a), are underlain by a variety of clastic sedimentary bedrock. The relief in this district is generally bedrock controlled with a thin veneer of glacial till, resulting in a smooth, undulating terrain with low relief knolls and valleys, covered by a mixed deciduous, coniferous Acadian Forest. Given the high water surplus, first-order flow systems (Toth 1962) dominate.

(2) The Windsor District (Fig. 4b) is found in the lowest relief areas, comprising easily erodible argillaceous clastics, evaporites and limestones. Karst is present in various stages of hydrologeological development (Baechler and Boehner 2014), including channels at depth infilled with sand and gravel (Fig. 4b). Underlying the deeper drift controlled lowlands of the River Denys, Inhabitants and Hawthorne/ Moran basins are isolated channel fills and/or eskers surrounded by thick sequences of fine grained tills and lacustrine clays (Fig. 4c).

(3) The Alluvial Valley District includes large river valleys which may be underlain by evaporite rocks and argillaceous clastic or arenaceous clastic sedimentary rocks (Fig. 5a).

(4) The Canyon Hydrological Region (Fig. 5b), which encompasses $8 \%$ of Cape Breton Island, is incised into the highland Paleogene/Neogene peneplain along largescale fault systems in various stages of exhumation and hydrogeological development (Baechler 2015). The valley floors tend to be underlain by crystalline basement bedrock, while down valley and under estuaries this can transition to clastic sedimentary rocks and/or evaporite rocks. Coarse, unconsolidated sediments associated with colluvium, talus cones, and alluvial fans locally overlie the valley floor along steep valley flanks.

\section{METHODS}

The data compiled and presented in this study came from 150 sites distributed across Cape Breton Island (Fig. 3). A total of 2555 well records were reviewed, $30 \%$ of which were drilled for hydrogeological purposes, 25\% for geotechnical studies, $3 \%$ for geological delineation, and $42 \%$ from the Nova Scotia Department of Environment's (NSE) provincial water well database (http://novascotia.ca/natr/meb/ download/dp430.asp). Additional data included results from 17 pumping tests, 46 slug tests, 240 grain-size analyses and 126 water chemical analyses within these aquifers. It is important to note that the spatial distribution of this database is not random. Wells were drilled on specific targets and can include clusters around select sites. Geotechnical investigations supporting bridge designs focus at the edge of present-day channels, which may not be positioned over any buried channel.

For the purposes of this paper BBVs are defined where previous drilling has indicated a depth to bedrock in excess of $10 \mathrm{~m}$, regardless of the nature of infill. Sand and gravel aquifers were defined in these valleys using the following nomenclature: (1) "proven" where detailed lithological logs were available; (2) "probable" where domestic water wells with poor lithologic logs showed completion in overburden 


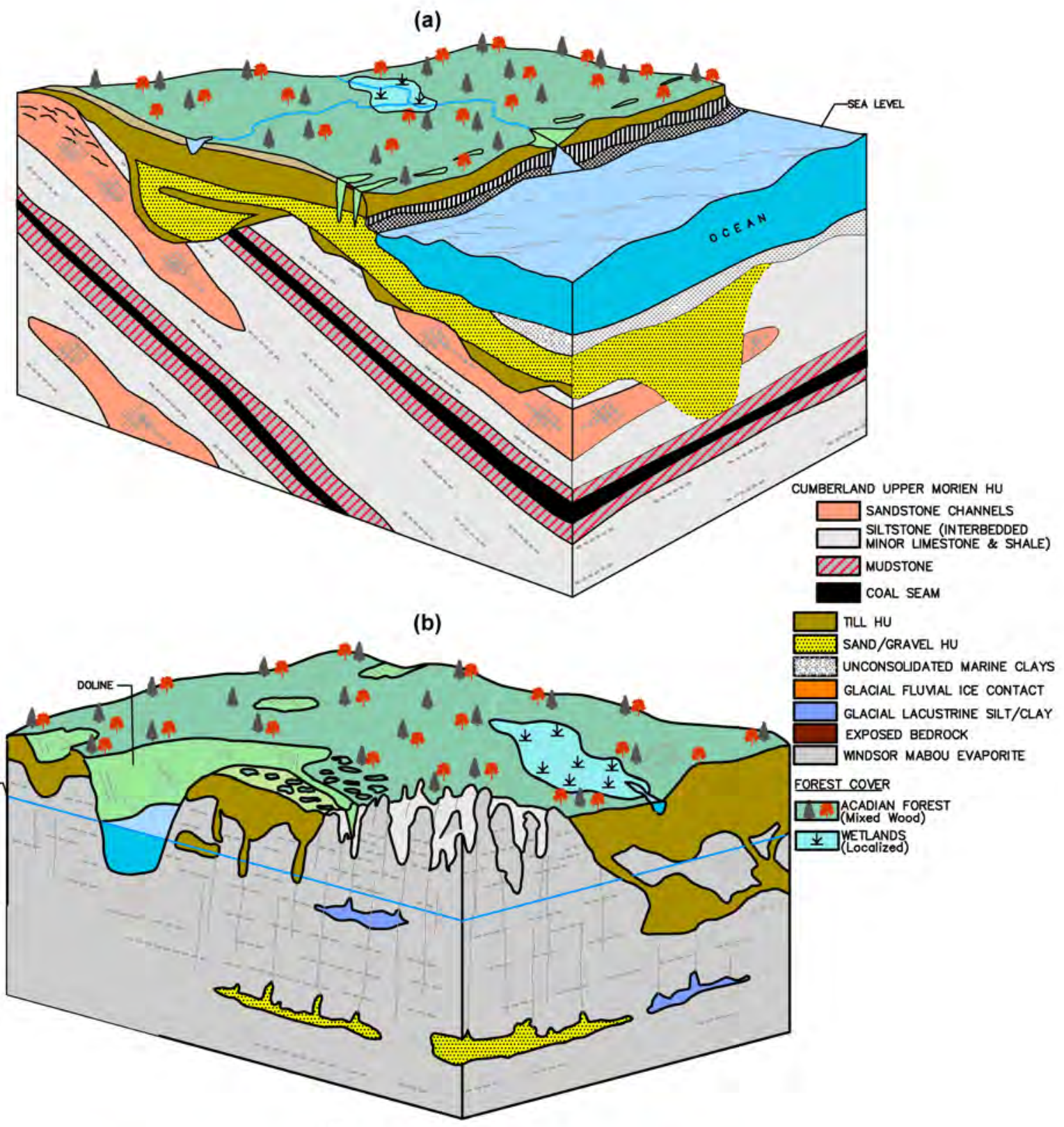

(c)

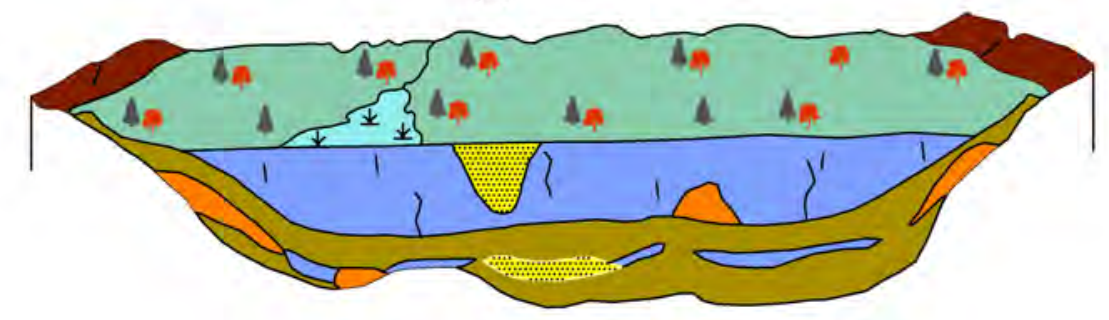

Figure 4. Conceptual 3-D block models for BBV valley aquifers in the Lowland Hydrological Region; Homoclinal Flank (Fig. 4a) and Windsor Hydrological Districts, including both karst-dominated (Fig. 4b) and deep Quaternary sedimentfilled basins (Fig. 4c). 
(a)

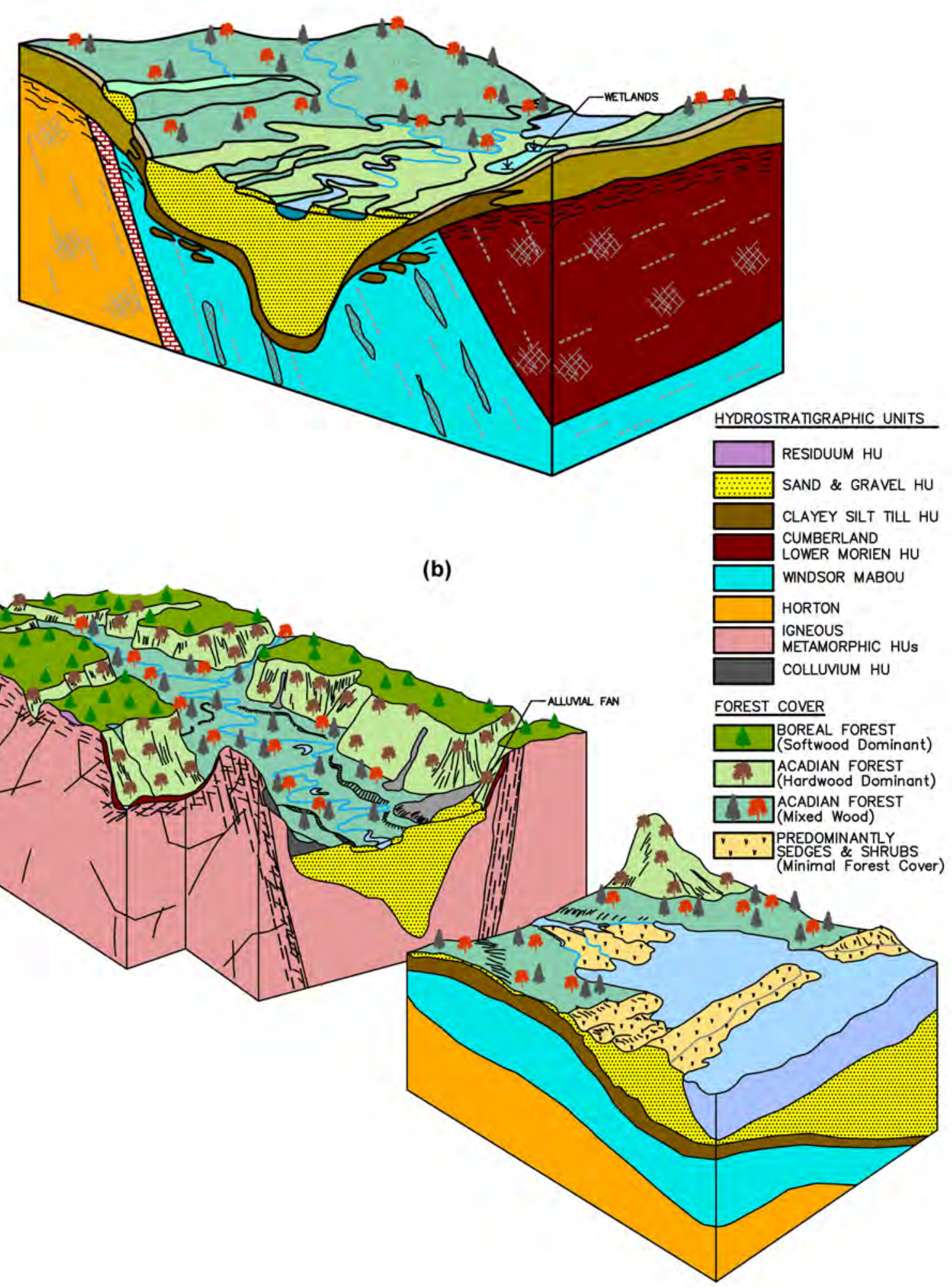

Figure 5. Conceptual 3-D block models for BBV aquifers in the Lowland Hydrological Region Alluvial Valley District (Fig. 5a) and Canyon Hydrological Region (Fig. 5b). 
at depths exceeding $10 \mathrm{~m}$; and (3) "possible" where shoreline exposures suggested the presence of such conditions, where detailed lithological logs intercepted localized sand and gravel units at depth in deep Quaternary basin fills but lateral continuity was unknown, and where thin, sheet-style sand and gravel units were documented with drilling to depth in bedrock, but an associated deeper channel was not found. Aquifer materials include Cretaceous unconsolidated fluvial deposits, Pleistocene glaciofluvial deposits and/or Holocene fluvial, colluvial, and alluvial fan sequences.

The data sets developed for this paper have been provided to the Nova Scotia Department of Natural Resources for inclusion in their water resources data base.

\section{RESULTS}

Of the 150 sites investigated, $61 \%$ exhibited evidence for a BBV aquifer, of which, 28\% were "proven", 24\% "probable" and 9\% "possible" (Fig. 3). Approximately $90 \%$ are associated with major river systems within the Canyon and Lowland Hydrological regions. Of the remaining sites, 5\% are within deep Quaternary basin lowland fills, $2 \%$ are exposed along shorelines, and 3\% are associated with infilled karst channels at depth in limestone, gypsum, and anhydrite. This information suggests that more BBV aquifers may exist than presently mapped.

A summary of transmissivities, storativity, 20-year safe yields from pumping tests, and hydraulic conductivities from slug tests are provided in Table 1. The classification of transmissivity follows Krasny (1993). Records for 17 pump tests were available for wells ranging from 4 to 37 $\mathrm{m}$ deep. Well transmissivity ranged from "low" to "very high" (14 to $1939 \mathrm{~m}^{2} / \mathrm{d}$ ). A total of seven hydraulic tests had one or more observation wells, allowing calculation of an aquifer transmissivity, which ranged from 22 to 1570 $\mathrm{m}^{2} / \mathrm{d}$. Generally, the "high" to "very high" range (232 to $1939 \mathrm{~m}^{2} / \mathrm{d}$ ) is associated with gravel-dominated aquifers. Storage coefficients ranged from $2.0 \times 10^{-1}$ to $5.0 \times 10^{-3}$ with three semi-confined values ranging from $6.1 \times 10^{-4}$ to 5.0 $\times 10^{-5}$. Thirty-four slug tests provided a range in hydraulic conductivity from $9.0 \times 10^{-3}$ to $5.1 \times 10^{-6} \mathrm{~cm} / \mathrm{sec}$. The lower end of the range is associated with $\mathrm{N}$ channels compacted by glacial overriding and interbedded till layers.

Representative water chemistries were available for 34 wells ranging in depth from 2 to $32 \mathrm{~m}$. The inorganic chemical signature is summarized in a piper plot (Fig. 6). The groundwater chemistry exhibits wide variability in five hydrochemical (HC) facies. The initial input from recharge (HC-1) is similar to rainwater, encompassing shallow groundwater with a thin unsaturated zone, no overlying till, and/or in proximity to a stream channel. This grouping is characterized by relatively low total dissolved solids (TDS) ranging from 20 to $70 \mathrm{mg} / \mathrm{L}$, a sodium chloride to sodium/calcium - chloride/bicarbonate type water, with slightly acidic $\mathrm{pH}$ (5.8 to 6.2). HC-1 transitions into the dominant core (HC-2) calcium bicarbonate type. This is characterized as a fresh (TDS ranging between 70 to 316 $\mathrm{mg} / \mathrm{L}$ ), hard (hardness as $\mathrm{CaCO}_{3}$ ranging between 40 and $225 \mathrm{mg} / \mathrm{L}$ ), primarily corrosive water, with predominately alkaline $\mathrm{pH}(6.9$ to 8.1$)$ and alkalinity $\left(\right.$ as $\left.\mathrm{CaCO}_{3}\right)$ of 35 to $160 \mathrm{mg} / \mathrm{L}$. There is a gradual transition from the core group to three other HCs. HC-3 and HC-4 are related to the influence of higher TDS (1000 to $3390 \mathrm{mg} / \mathrm{L}$ ) waters in the deeper portion of the aquifers within regional groundwater discharge zones. They are influenced by underlying evaporite sequences, including calcium sulfate (HC-3) and sodium chloride-types (HC-4). HC-5 exhibits a trend toward a sodium bicarbonate, naturally softened water, associated with underlying mudstone-shale-coal sequences. Three hydrogeological case studies are outlined below to exemplify conceptual models for one of the Lowland Regions (Fig. 5a) and the Canyon Region (Fig. 5b).

\section{CAPE BRETON ISLAND HYDROGEOLOGICAL CASE STUDIES}

\section{Case study 1: Broad Cove River Aquifer}

The Broad Cove River Aquifer (Figs. 3 and 7) exemplifies an unconfined, Type I, BBV aquifer underlying a valley floor within the Lowland Hydrological Region, Alluvial Valley District (Fig. 5a). The mapped surface expression (Fig. 7a) ranges from 1 to $3 \mathrm{~km}$ in width and $13 \mathrm{~km}$ in length (Grant 1994). Its $37 \mathrm{~km}^{2}$ area is confined by smooth, low-slope valley flanks, which rise to uplands reaching 100 to $250 \mathrm{~m}$ above the valley floor. Land use historically comprised forestry and agriculture, and is now augmented by transportation corridors, commercial, suburban and rural use, a municipal landfill, a forest nursery, and a golf course. The Broad Cove River BBV aquifer is the largest, and arguably the second most heavily utilized, on Cape Breton Island.

Hydrogeologicalinvestigationswereoriginally undertaken to develop a groundwater supply for the Village of Inverness (Pinder 1966; ADI Ltd. 2002a) and the Strathlorne Forest Nursery (Baechler 1980). Hydrogeological investigations for the Kenloch landfill were undertaken by Baechler (1979), Nolan Davis Ltd. (1990), ADI Ltd. (2002b) and Exp Services Inc (2014). Kennedy (2014) provided a preliminary outline of the hydrogeology of the aquifer. The data comprised logs from 81 wells of which, $69 \%$ were detailed logs from groundwater, geotechnical, and geological studies and 31\% were domestic water wells. Associated studies provided information from five pump tests, 19 slug tests, 32 grain size analyses, and 64 representative groundwater chemistries. Production wells (PW1 and PW2) for the Village of Inverness have been operating within this aquifer for 50 
Table 1. Hydrogeological characteristics of the sand/gravel hydrostratigraphic unit.

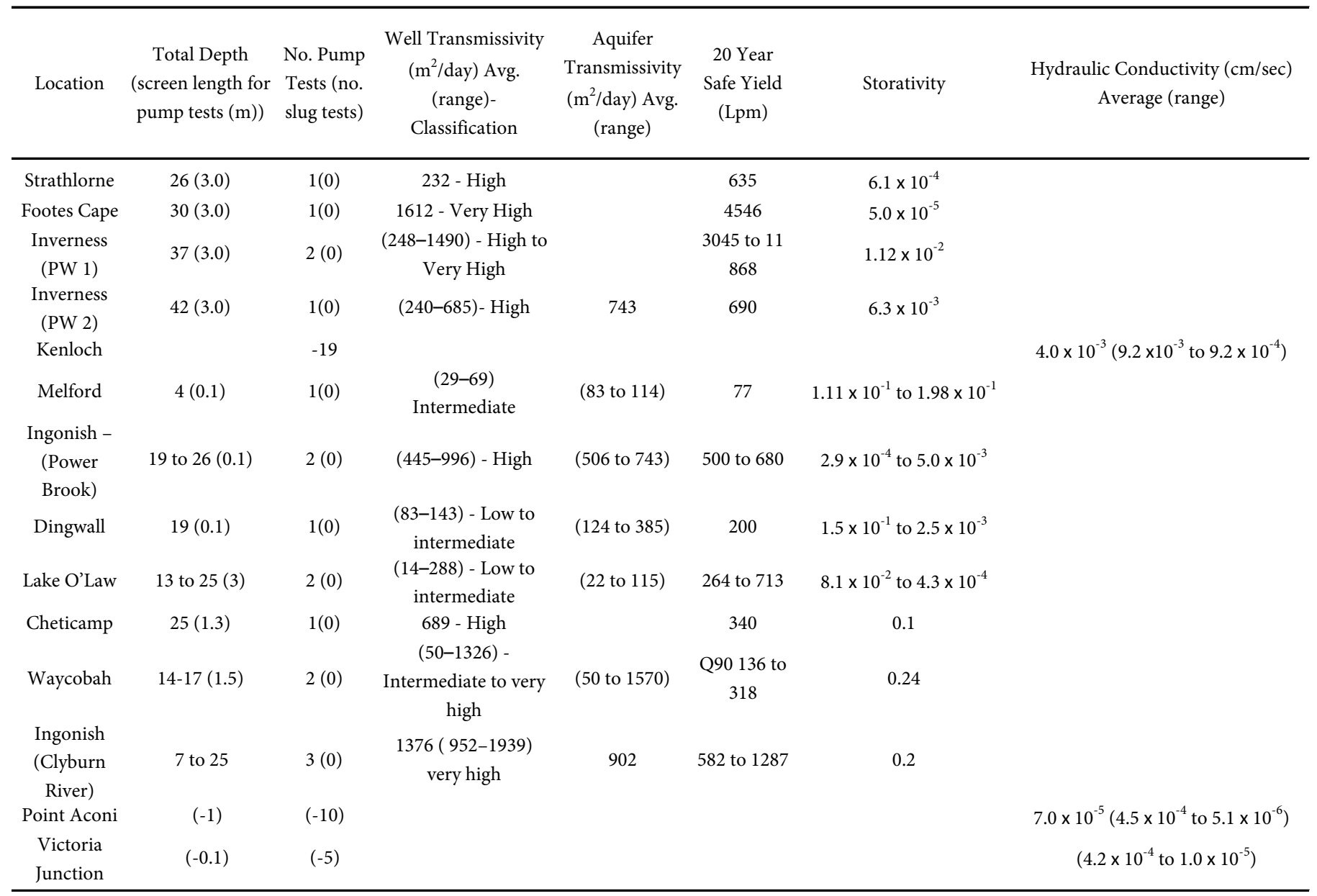

NOTE: 0.1 screened interval implies open at the bottom of the casing.

and 14 years, respectively; the Strathlorne Nursery well has been operational for 35 years (Fig. 7b). The narrowly incised bedrock channel (Fig. $7 \mathrm{~b}$ ) is positioned generally in the centre of the valley. The base of the channel at Inverness extends to depths of between $20.1 \mathrm{~m}$ (-14.5 m geodetic) and $40.0 \mathrm{~m}$ (-10 m geodetic).

The aquifer is sand dominated, with thin ( 1 to $2 \mathrm{~m}$ ), localized beds of sand and gravel. No glacial till, lacustrine/ marine clays, or diamictons have been noted. The $3 \mathrm{~km}$ long, 0.5 to $0.9 \mathrm{~m}$ wide Kenloch kame moraine (Figs. $7 \mathrm{~b}$ and $7 \mathrm{c}$ ) overlies the buried channel and attains an elevation of some $60 \mathrm{~m}$ above the valley floor (Baechler 1979). The moraine is sand dominated with a diamicton and/or glacio-lacustine deposits positioned above the bedrock. Gravels locally overlie the sand under ridge knolls, with a sandy diamicton draped over the surface. Nineteen grain size analyses noted a slightly calcareous, fine sand with a distribution of gravel $0 \%$, sand $70 \%$ (range 15-97\%) and silt clay 30\% (range 3-85\%).

Production wells at depths of 26 to 30 m near Strathlorne screened in gravels provided transmissivities of 232 to 1612 $\mathrm{m}^{2} / \mathrm{d}$, with storativity in the semi-confined range from $6.1 \times 10^{-4}$ to $5.0 \times 10^{-5}$. Further down valley the Inverness production wells at depths of 35 to $40 \mathrm{~m}$, positioned in the centre of the channel, exhibited transmissivities of 248 to $1490 \mathrm{~m}^{2} / \mathrm{d}$ (PW1), and 240 to $685 \mathrm{~m}^{2} / \mathrm{d}$ (PW 2); with an aquifer transmissivity of $743 \mathrm{~m}^{2} / \mathrm{d}$. The storativity ranged from $1.12 \times 10^{-2}$ to $6.3 \times 10^{-3}$. The hydraulic conductivity for kame moraine sand from 19 sites provided an average of 4.0 $\times 10^{-3} \mathrm{~cm} / \mathrm{sec}$, ranging from $9.2 \times 10^{-3}$ to $2.0 \times 10^{-4} \mathrm{~cm} / \mathrm{sec}$.

The water table is relatively shallow, ( 1 to $6 \mathrm{~m}$ ) supporting the perennial streams, and a number of wetlands. However, the water table has been recorded at depths of 15 to 30 $\mathrm{m}$ below the crest of the adjacent kame moraine. This configuration allows Lake Ainslie to direct groundwater outflow through the BBV aquifer under the kame moraine (Fig. 7c) (Baechler 1979).

Groundwater stream interaction maintains the perennial Broad Cove River. At Strathlorne the $35.8 \mathrm{~km}^{2}$ watershed has created a 8 to $10 \mathrm{~m}$ wide, $101^{\text {st }}$ Shreve stream order 

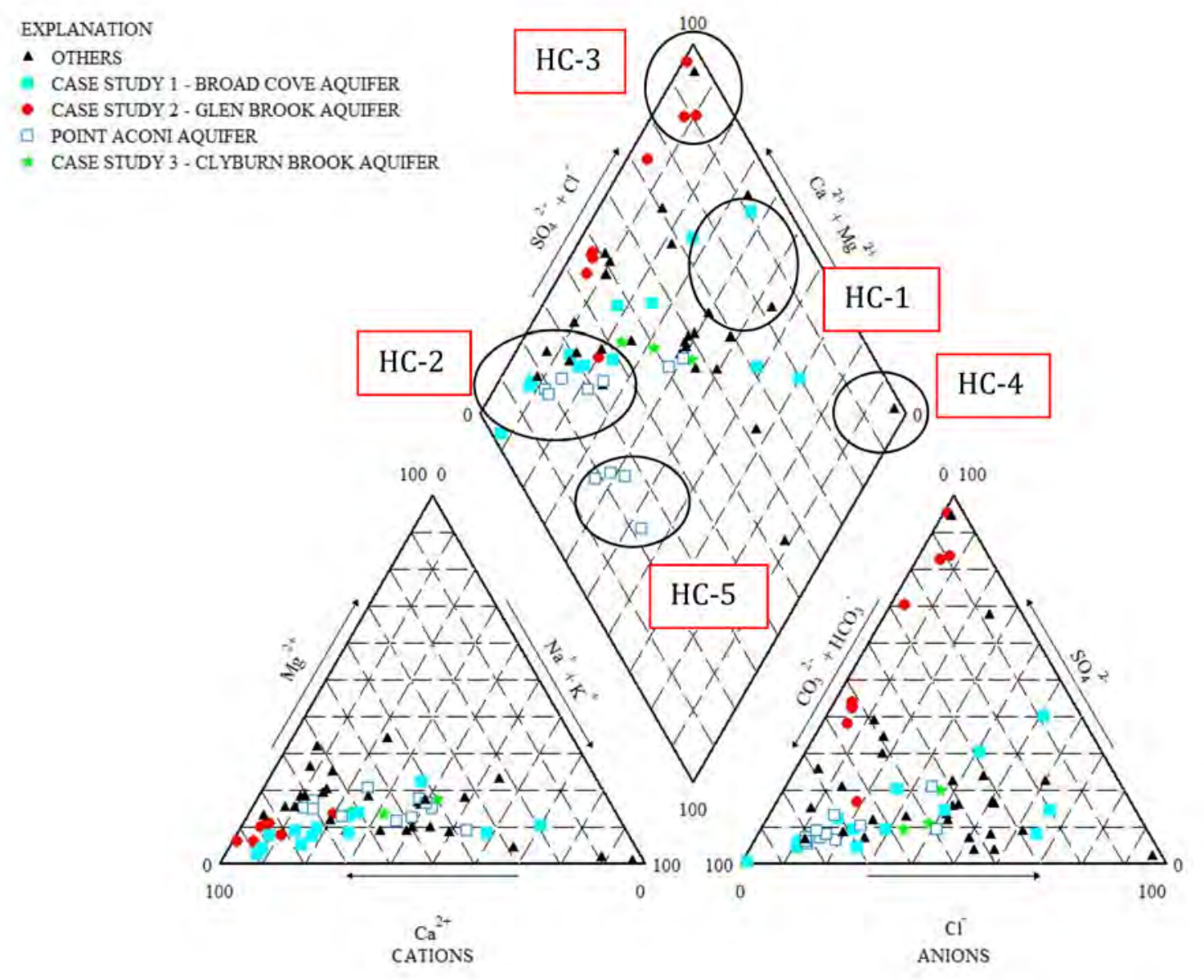

Figure 6. Tri-linear plot of major ion chemistries of BBV aquifers obtained from the three case studies, as well as other sites.

channel with a gradient of 0.2 to $0.3 \%$. At a Rosgen Level 1 (Rosgen and Silvey 1998), it is qualitatively classed as a C4 to $\mathrm{C} 5$ channel, exhibiting a riffle-run-pool morphology. The channel is incised generally 1 to $3 \mathrm{~m}$ into the aquifer.

Shallow groundwater chemistry below a 6 to $7 \mathrm{~m}$ unsaturated zone generally exhibits a fresh (TDS 20 to 30 $\mathrm{mg} / \mathrm{L}$ ), soft (3 to $8 \mathrm{mg} / \mathrm{L}$ as $\mathrm{CaCO}_{3}$ ), corrosive, sodium chloride-type water (Fig. 6), with a low pH (4.9 to 5.9) and total alkalinity (as $\mathrm{CaCO}_{3}$ ) ranging between $<1$ to $10 \mathrm{mg} / \mathrm{L}$. With an increase in unsaturated zone of up to $20 \mathrm{~m}$, the chemistry exhibits an increase in TDS ( 97 to $260 \mathrm{mg} / \mathrm{L}$ ) and hardness (70 to $140 \mathrm{mg} / \mathrm{L}$ as $\mathrm{CaCO}_{3}$ ), while changing to a calcium bicarbonate type water (Fig. 6) with a rise in $\mathrm{pH}$ (7.4 to 8.1 ) and total alkalinity (77 to $160 \mathrm{mg} / \mathrm{L}$ ). Inverness PW2, positioned from near the base of the incised channel in a regional discharge zone, exhibits a fresh (TDS 445 $\mathrm{mg} / \mathrm{L})$, very hard $(310 \mathrm{mg} / \mathrm{L})$, encrusting calcium chloridetype water with a $\mathrm{pH}$ of 7.8 and total alkalinity of $118 \mathrm{mg} / \mathrm{L}$.

Base metals at detectable concentrations in 13 samples included iron ( 0.02 to $0.45 \mathrm{mg} / \mathrm{L}$ ), manganese (0.01 to 0.77 $\mathrm{mg} / \mathrm{L}$ ), barium $(0.02$ to $0.38 \mathrm{mg} / \mathrm{L}$ ), copper (0.01 to 0.05 $\mathrm{mg} / \mathrm{L}$ ), zinc (0.01 to $0.18 \mathrm{mg} / \mathrm{L})$, and strontium (0.01 to 0.4 $\mathrm{mg} / \mathrm{L})$. Arsenic was not detectable.

Historical forestry and agricultural land use has not impacted nutrient concentrations, as noted with nitrogen (nitrite +nitrate as N) at $<0.05$ to $0.58 \mathrm{mg} / \mathrm{L}$. Radiologicals monitored at PW2 as represented by uranium $(<0.0001$ $\mathrm{mg} / \mathrm{L})$, gross alpha and beta $(<0.1 \mathrm{~Bq} / \mathrm{L})$, and radon gas $(18$ $\mathrm{Bq} / \mathrm{L}$ ) were at low concentrations (ADI Ltd. 2002a). Although the "oil fields" of Cape Breton Island have been reported in the Inverness and Lake Ainslie areas (McMahon et al. 1986), hydrocarbons have not been detected at two background sites.

Ongoing monitoring of baseline hydrogeological conditions within this buried valley aquifer is localized and infrequent. Monitoring of background conditions (Exp Services Inc. 2017) once per year during late summer for 27 years (Fig. 8) has indicated no qualitatively, long-term trends in either water level or four indicator chemical parameters. 
(a)

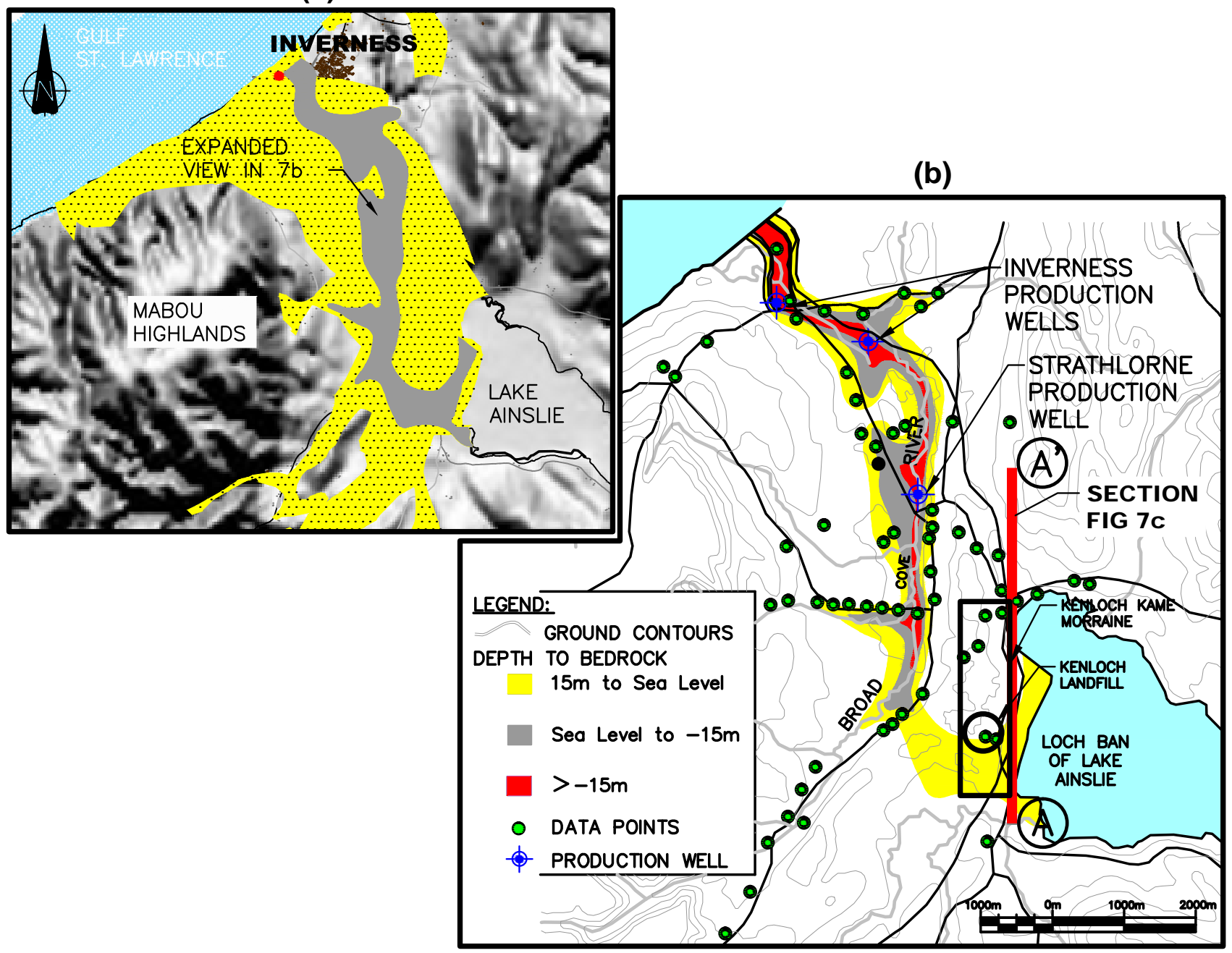

A

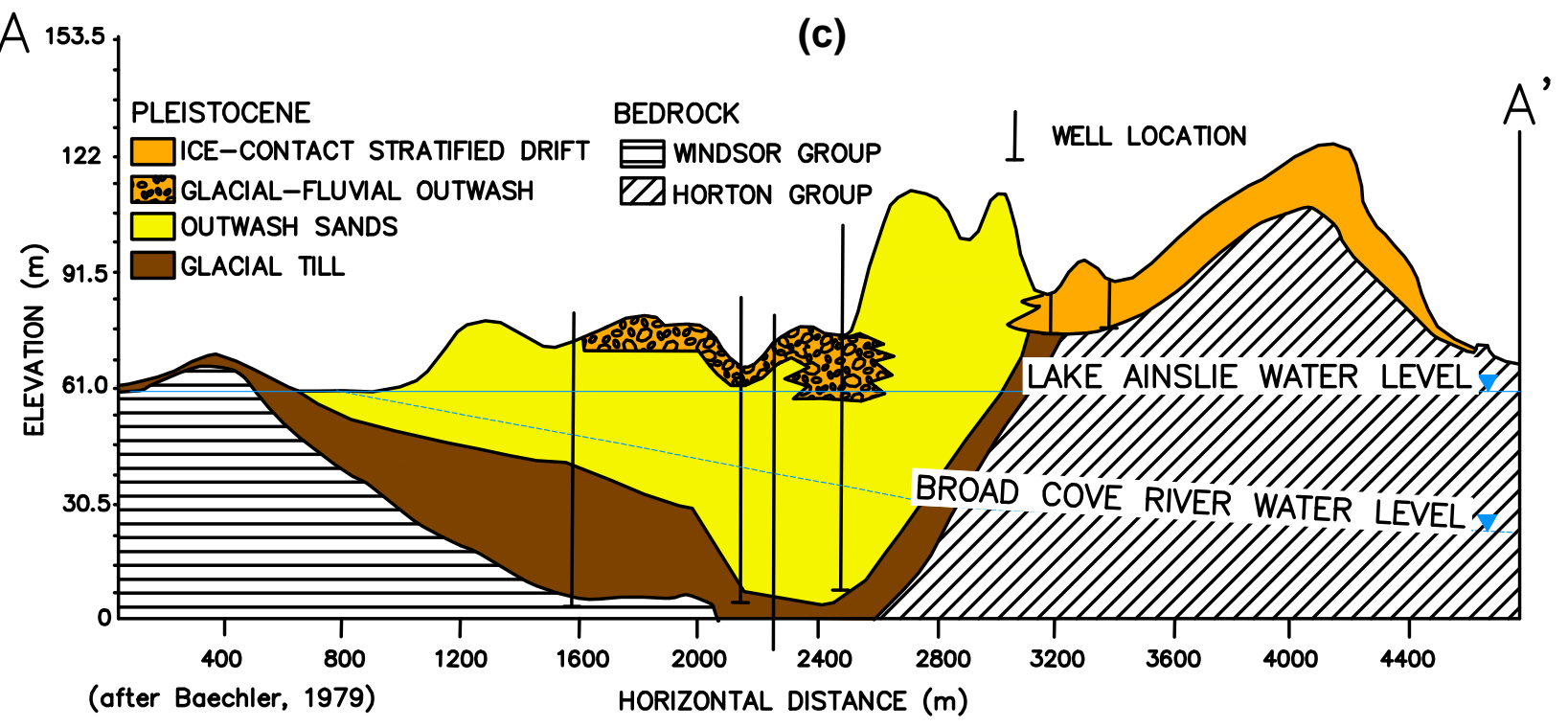

Figure 7. Location (a), mapped aerial extent (b), and vertical configuration (c) of the Broad Cove BBV aquifer at Inverness, as summarized from various sources. 


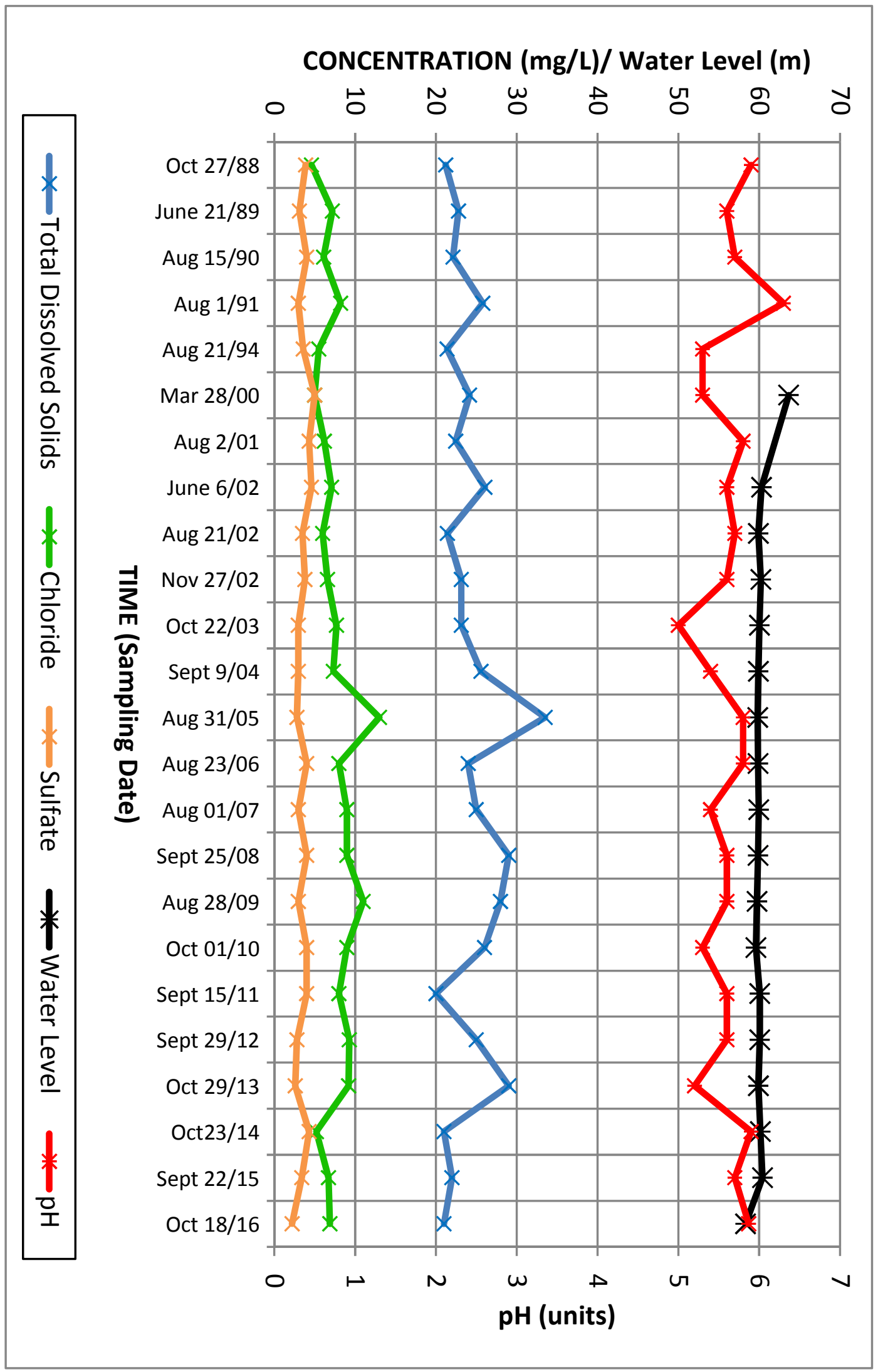

Figure 8. Long-term trends in indicator parameters within the Broad Cove River aquifer at Kenloch from 1988 to 2015. 


\section{Case study two: Glen Brook Aquifer}

The Glen Brook Aquifer (Figs. 3 and 9) is similar to the Broad Cove River aquifer as it exemplifies a surficially mapped (Grant 1994; Stea et al. 2006), unconfined, Type 1 bedrock valley aquifer underlying a regional valley floor in the Lowland Hydrological Region, Alluvial Valley District (Figs. 5a and 9a). It is the most intensively studied BBV aquifer on the island. Its distinctive nature accommodates both Type 1 glaciofluvial deposits as well as Type 4 Cretaceous sands and clays. Upward regional flow into the base of the aquifer originates from evaporite deposits. Groundwater stream interaction provides critically important habitat for salmonids (ADI Ltd. May 2000). The Glen Brook Aquifer has provided an adjacent gypsum mine with its water supply for 14 years. Land usage above the aquifer was historically farming and forestry, but now includes mining, with headwaters in the Bornish Hills Nature Reserve.

A $2.7 \mathrm{~km}$ reach of the Type 1 deposit was investigated as a salmonid management zone associated with development of an adjacent gypsum mine by Georgia Pacific Canada LP (ADI Ltd. 1999, 2000, 2001; Henley et al. 2009). The findings from this study comprise 69 well logs associated with groundwater, geotechnical, and geological studies, data from one pump test, 10 slug tests, 32 grain-size analyses, and representative groundwater chemistries. It also includes 19 years of interdisciplinary studies providing 177 stream discharge/stage and head levels at five wells, as well as 188 surface water chemistries.

The Type 4 deposit covers $0.14 \mathrm{~km}^{2}$ at the base of a steepsided, V-shaped gorge (Fig. 9b). The deposit is approximately $700 \mathrm{~m}$ long by $200 \mathrm{~m}$ wide and up to $120 \mathrm{~m}$ deep, comprising $96 \mathrm{~m}$ of silica sand, underlain by $25 \mathrm{~m}$ of clay (Fig. 9b). The Type 1 deposit occurs beneath a broad valley floor, ranging in width from 100 to $800 \mathrm{~m}$ and some $2.2 \mathrm{~km}$ in length (Fig. 9c), covering approximately $0.9 \mathrm{~km}^{2}$. The northeast side of this broad valley is shallow, rising to approximately $25 \mathrm{~m}$ above the valley floor, exhibiting glacial till overlying karstdominated evaporite rocks. To the southwest, the valley is steep, rising to approximately $225 \mathrm{~m}$ above the valley floor and underlain by faulted sandstone and conglomerate. The aquifer reaches a depth of at least $30 \mathrm{~m}$ (-10 m geodetic), where it is underlain by at least an additional $15 \mathrm{~m}$ of till (Fig. 9c). The Type 1 deposit extends southeastward downstream of the study site, into the Denys Basin lowland, where an unconfined, sand-dominated channel (Fig. 9d), up to $30 \mathrm{~m}$ deep and bounded by a thick sequence of tills and lacustrine deposits, was mapped by Stea et al. (2006).

The glaciofluvial deposits are predominately well sorted, very fine sand with numerous, thin $(1$ to $30 \mathrm{~cm})$ silt/clay lenses throughout. Sixteen grain size analyses indicate $<0.5 \%$ gravel (ranging from 0 to $2 \%$ ), $65 \%$ sand (3 to $99 \%$ ) and $35 \%$ fines (1 to $97 \%$ ). A near-surface gravel facies is on average, $2.0 \mathrm{~m}$ thick, ranging from 1 to $4 \mathrm{~m}$, based upon 41 test pit locations. It generally comprises poorly sorted compact sand and gravel with no apparent stratification. A total of 11 grain-size analyses indicate $46 \%$ gravel (0 to $26 \%$ ), $50 \%$ sand (30 to $70 \%$ ) and $4 \%$ fines (4 to $12 \%$ ). Hydraulic testing of a dug well within the gravel facies provided well transmissivities ranging from 29 to $69 \mathrm{~m}^{2} /$ day and aquifer transmissivities ranging from 83 to $114 \mathrm{~m}^{2} / \mathrm{d}$. Storativity ranged from 1.14 to $1.98 \times 10^{-1}$. Three hydraulic conductivity values for the sand averaged $1 \times 10^{-3} \mathrm{~cm} / \mathrm{sec}$. (ranging from $2 \times 10^{-3}$ to $3 \times 10^{-4} \mathrm{~cm} / \mathrm{sec}$ ). Seven hydraulic conductivity values for the gravel averaged $1.2 \times 10^{-3} \mathrm{~cm} / \mathrm{sec}\left(1.9 \times 10^{-3}\right.$ to $5.3 \times 10^{-4} \mathrm{~cm} / \mathrm{sec}$ ).

Groundwater-stream interaction is maintained by a high water table within the gravel facies, altered locally by beaver dams. One shallow well within $10 \mathrm{~m}$ of the main channel noted an effluent reach with continuous water levels above the stream channel (Fig. 10). The $16.8 \mathrm{~km}^{2}$ watershed has created a perennial, 8 to $12 \mathrm{~m}$ wide, $10^{\text {th }}$ Shreve stream order channel with a gradient of 0.4 to $0.5 \%$. At a Rosgen Level 1 (Rosgen and Silvey 1998) it is qualitatively classed as a C4 to C5 channel exhibiting a riffle-run-pool morphology with localized braided reaches. The large width/depth ratio (12 to 26) channel is incised 1 to $4 \mathrm{~m}$ into the aquifer. Groundwater discharge into effluent reaches of the channel ranged from 2 $\times 10^{-3}$ to $1 \times 10^{-4} \mathrm{~cm} / \mathrm{sec}$ per unit area of stream; with influent reaches also present (Henley et al. 2009). Active channel migration facilitates erosion of a gravel facies of the aquifer for re-distribution by bedload transport into riffle, runs, and pools, creating excellent habitat for benthic invertebrates to support salmonids (ADI Ltd. May 2000).

A total of seven representative groundwater chemistries collected at the water table indicated a fresh (TDS 70-454 $\mathrm{mg} / \mathrm{L}$ ), soft to hard (46 to $353 \mathrm{mg} / \mathrm{L}$ as $\mathrm{CaCO}_{3}$ ), corrosive to encrusting, mixed calcium-bicarbonate/sulfate-type water (Fig. 6), with a slightly alkaline $\mathrm{pH}$ (6.3 to 7.7 ) and total alkalinity of $44-131 \mathrm{mg} / \mathrm{L}$. Near the base of the aquifer, the chemistry was altered by underlying evaporites creating a brackish (1060-1420 mg/L), very hard (803-935 mg/L), encrusting calcium sulfate-type water, with a slightly alkaline $\mathrm{pH}$ (7.7 to 7.8$)$ and elevated total alkalinity (111$120 \mathrm{mg} / \mathrm{L}$ ). Base metals were above detection in most samples and included iron $(<0.2$ to $0.71 \mathrm{mg} / \mathrm{L})$, manganese $(<0.02$ to $1.3 \mathrm{mg} / \mathrm{L})$, zinc $(<0.02$ to $0.03 \mathrm{mg} / \mathrm{L})$, aluminum $(<0.01$ to $0.46 \mathrm{mg} / \mathrm{L})$, barium $(<0.03$ to $0.12 \mathrm{mg} / \mathrm{L})$, boron $(<0.05$ to $0.51 \mathrm{mg} / \mathrm{L})$, and strontium $(0.16$ to 4100 $\mathrm{mg} / \mathrm{L}$ ). Arsenic was consistently non-detectable. Nitrogen (nitrite+nitrate as $\mathrm{N}$ ) as an indicator of previous agricultural and forestry practices was characterized by non-detectable to low concentrations $(<0.05$ to $0.10 \mathrm{mg} / \mathrm{L})$. Uranium, as an indicator of radiologicals, was consistently detectable, but at low concentrations $(0.0002$ to $0.0016 \mathrm{mg} / \mathrm{L})$. Total petroleum hydrocarbons have not been detected within stream channel under baseflow conditions during the 19- 
(a)

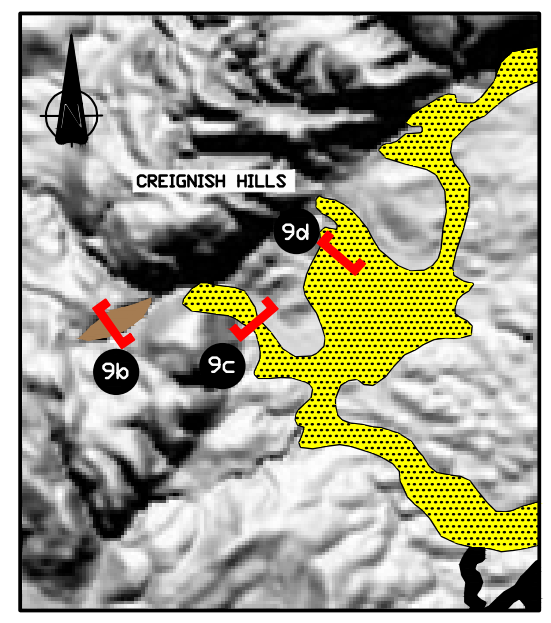

(b)

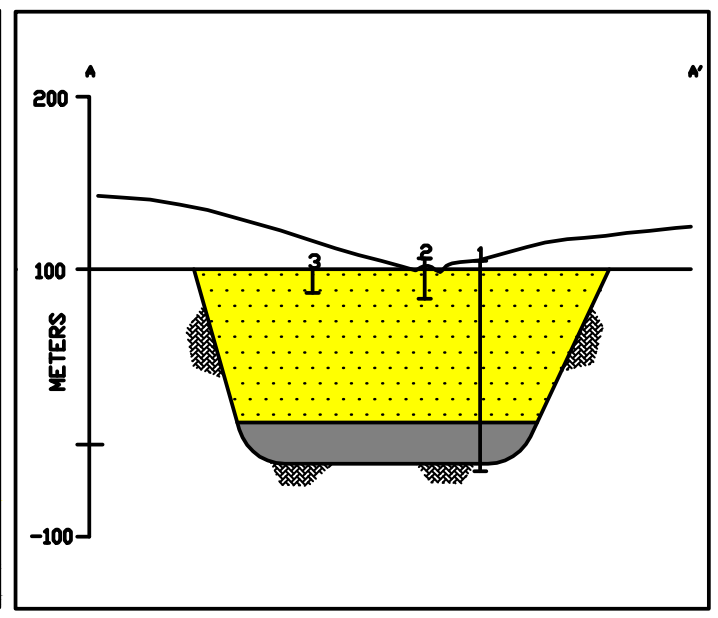

(d)

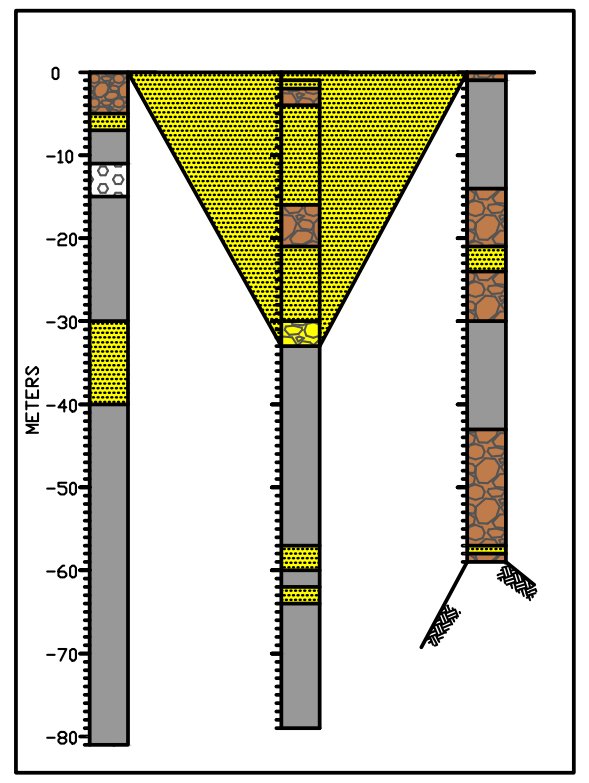

(c)

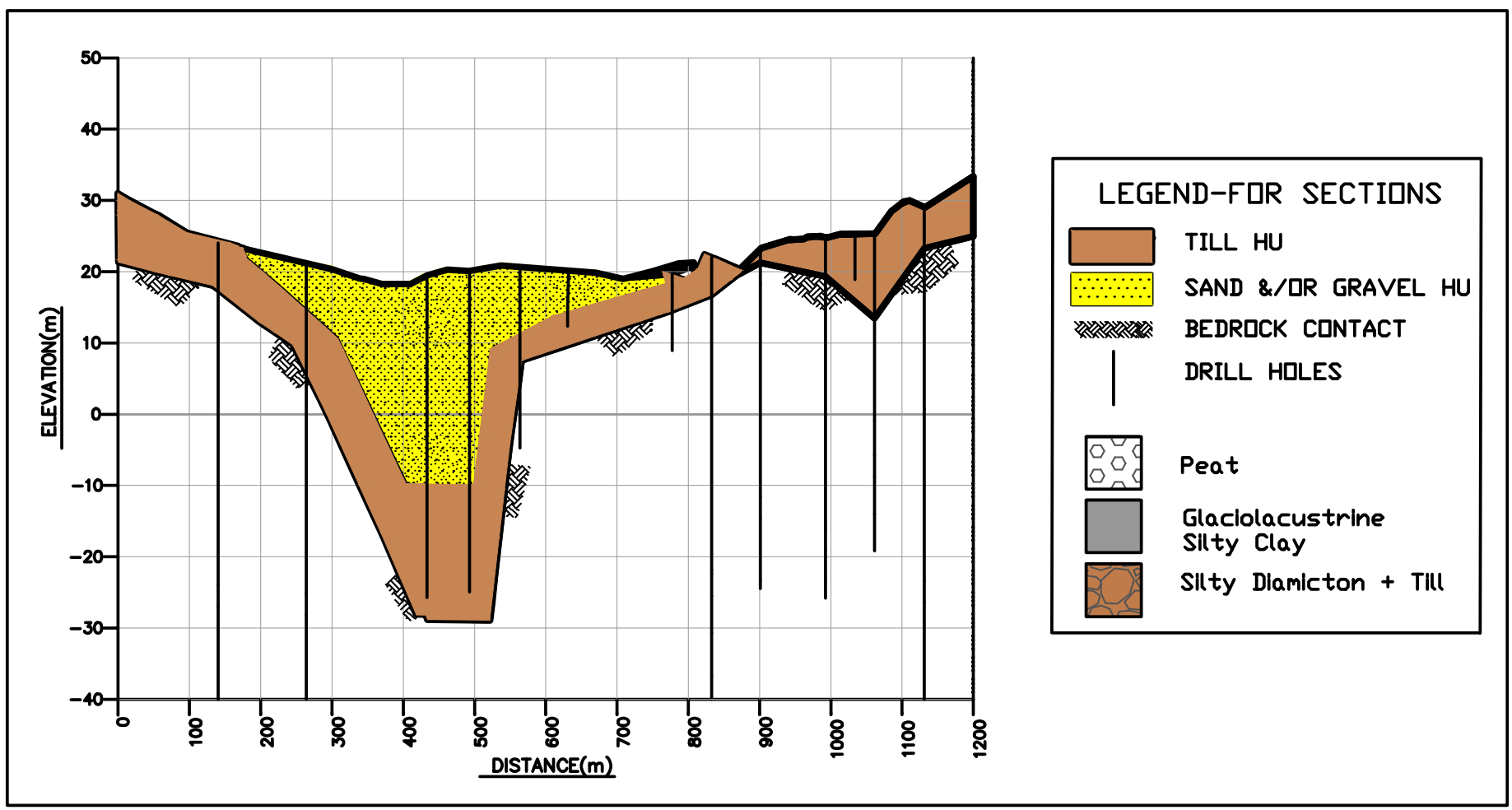

Figure 9. Location, mapped aerial extent (a), and vertical configuration (b, c, d) of the Glen Brook buried bedrock valley aquifer at Melford, as summarized from various sources. 


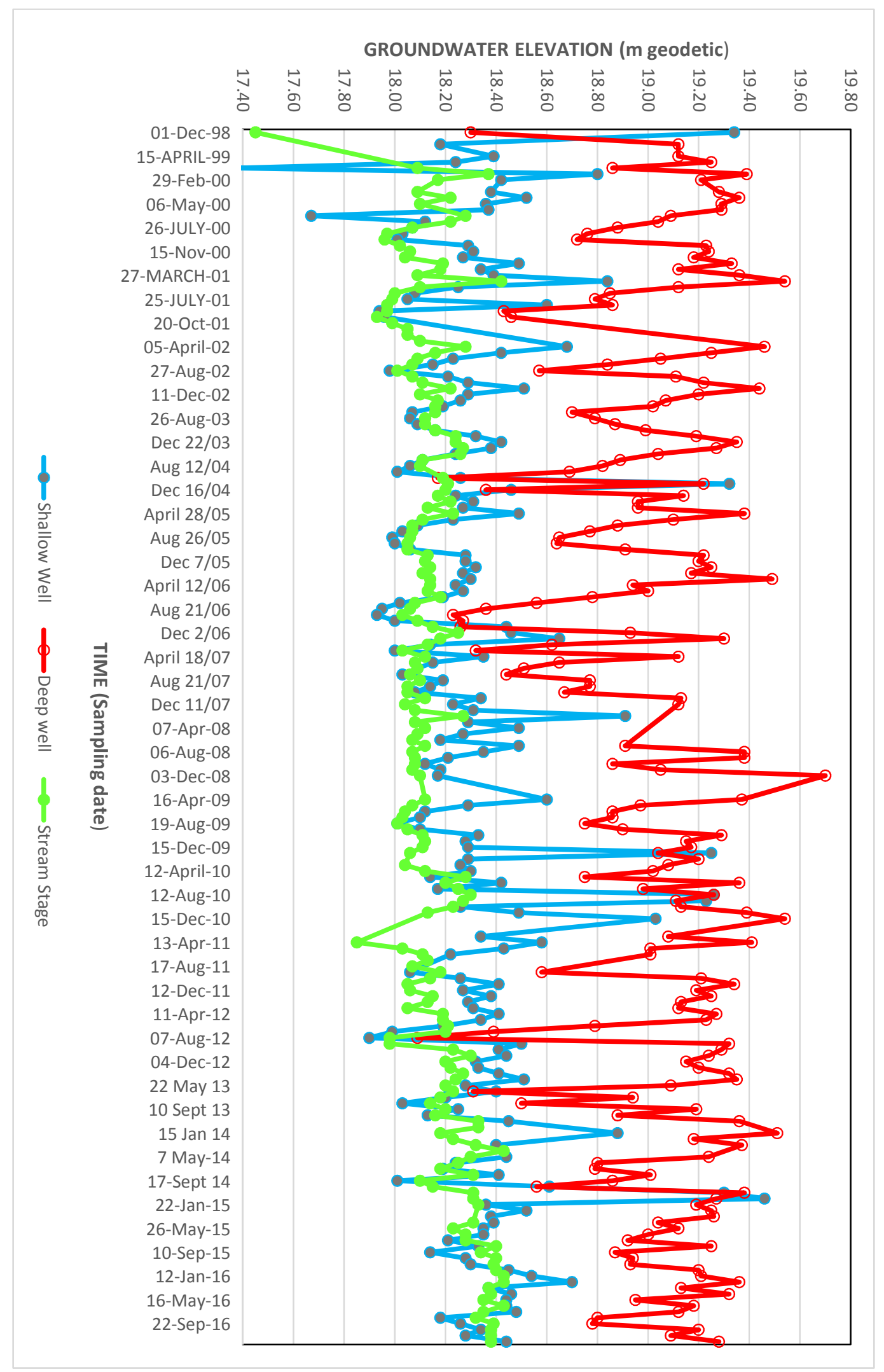

Figure 10. Long-term trends in indicator parameters within the Glen Brook aquifer from 1998 to 2015. 
year monitoring period.

No monitoring occurs within the Type 4 Cretaceous deposit. Monitoring of the Type 1 glaciofluvial aquifer is localized and frequent (monthly). Nineteen years of monitoring has indicated no notable change in head level within the aquifer (Fig. 10).

\section{Case Study 3 - Clyburn River Aquifer}

The Clyburn River Aquifer (Figs. 3 and 11) exemplifies an unconfined, BBV aquifer within the Canyon Hydrological Region (Fig. 5b). This aquifer is distinctive in that: (1) the valley flanks are steep, rising to a canyon rim some 250 to 430 $\mathrm{m}$ above the valley floor; (2) the aquifer is bounded by low permeability crystalline bedrock; (3) the canyon received drainage from the Highland ice cap through to its demise around $10 \mathrm{ka}$ (Grant 1994), providing for longer-duration glacial melt flows and coarser sediment transport, creating a gravel dominated aquifer; (4) the steep valley flanks exhibit coarse, permeable sediments associated with colluvium, talus cones, and alluvial fans, and (5) the low permeable highland headwaters generate peak storm flow events, which enhances channel migration and flooding. The land surface and contributing watershed are protected within the Cape Breton Highlands National Park. A hardwood Acadian Forest dominates the aquifer and valley flanks, transitioning into Boreal softwood and Taiga forests with wetlands and rock barrens over the highland peneplain headwaters. The Highlands Links golf course surrounds the extraction site.

Hydrogeological investigations developed the irrigation supply for the Cape Breton Highlands golf course (CBCL Ltd. 1995a, 1995b, 1996). This was supported by geotechnical investigations for bridge and route alignments associated with the Cabot Trail (ADI Ltd. 2005; SNC Lavelin 2015). The reach of channel underlain by this BBV aquifer provides for salmonid habitat (ADI Nolan Davis Ltd. 1993). Channel training procedures have been implemented to protect pumping facilities and the golf course, as well as to maintain habitat (ADI Nolan Davis Ltd. 1993; Newbury Hydraulics 2011). The resultant data set included four production wells, one infiltration gallery, 24 groundwater monitoring wells and boreholes, 25 geotechnical holes, 41 domestic water supply wells, three pump tests, three grain-size analyses, and three representative water chemical analyses. The irrigation supply for the golf course has been in operation for over 19 years from production wells and for approximately 50 years from an infiltration gallery.

The $7 \mathrm{~km}$-long aquifer within the Clyburn River Canyon (Fig. 11a) ranges from 200 to $500 \mathrm{~m}$ in width, covering approximately $2.0 \mathrm{~km}^{2}$. It appears to be truncated just downstream of the extraction site by narrowing of the valley to $50 \mathrm{~m}$ and a bedrock sill under the present-day channel (Fig. $11 \mathrm{~b}$ ). The valley widens and the buried channel reappears downstream of the sill. The Type 1 aquifer is locally overlain by Type 3 permeable coarse gravel, cobble, and boulder sequences within colluvium, talus cones and alluvial fans resulting from Holocene erosion, creating influent, ephemeral tributary streams over its surface.

Hydrogeological studies for the water supply focused on a $0.4 \mathrm{~km}$ reach of channel immediately upstream of the bedrock sill. The depth of the aquifer increased upstream from 5.5 to $7.9 \mathrm{~m}$ near the sill to 14 to $>25 \mathrm{~m}$ towards the west (Fig. 11c). The deposit is poorly sorted sand and gravel, which locally becomes siltier below $5 \mathrm{~m}$ depth. Grain-size analyses indicated a range of gravel (26 to $49 \%$ ), sand ( 47 to $68 \%$ ) and silt (4 to $19 \%$ ). Geotechnical drilling $0.8 \mathrm{~km}$ downstream from the extraction site noted the buried valley was incised into crystalline basement to $25 \mathrm{~m}$ and infilled with a sand/gravel aquifer, which became coarser with depth. No till, lacustrine/marine clays or diamictons are present over, under or within the aquifer.

Testing of a $7 \mathrm{~m}$-deep infiltration gallery (Figs. $11 \mathrm{~b}$ and c) exhibited well transmissivity ranging from 1112 to $1236 \mathrm{~m}^{2} /$ day and aquifer transmissivity of $902 \mathrm{~m}^{2} / \mathrm{d}$; with storativity of $2.0 \times 10^{-1}$. A seven-day duration pumping test of PW2 and 3 -day duration test of PW5 provided well transmisivities of 952 and $1939 \mathrm{~m}^{2} / \mathrm{d}$, respectively. The resultant 20 year safe yields ranged from $>582 \mathrm{Lpm}$ for PW 5 to $1284 \mathrm{Lpm}$ for the infiltration gallery and $>1287 \mathrm{Lpm}$ for PW2.

Groundwater stream interaction is maintained by a high water table. At the groundwater extraction site, the $69.8 \mathrm{~km}^{2}$ watershed has created a perennial, 30 to $35 \mathrm{~m}$ wide, $30^{\text {th }}$ Shreve stream order channel with a gradient of 0.3 to $0.5 \%$. The large width/depth ratio (5 to 10 ) channel is incised only 1 to $2 \mathrm{~m}$ into the aquifer, with no signs of terracing. At a Rosgen Level 1 (Rosgen and Silvey 1998) it is qualitatively classed as a C3 to C4 channel, exhibiting a riffle-run-pool morphology; with localized braided reaches. This has created four salmon pools within $2 \mathrm{~km}$ around the extraction site (ADI Nolan Davis Ltd. 1993).

The infiltration gallery and production wells provide a fresh (TDS 30-92 mg/L), soft (10.8-14.8 mg/L as $\mathrm{CaCO}_{3}$ ), generally calcium-bicarbonate type water (Fig. 6). The shallow infiltration gallery exhibited a sodium/calcium bicarbonate-type water. The $\mathrm{pH}$ was slightly acidic (6.16.9) with an alkalinity of $11-32 \mathrm{mg} / \mathrm{L}$. Metal indicators of iron $(<0.01-0.15 \mathrm{mg} / \mathrm{L})$, manganese $(<0.01 \mathrm{mg} / \mathrm{L})$, and aluminum $(<0.01$ to $0.06 \mathrm{mg} / \mathrm{L})$ were at non-detectable to low concentrations.

The natural forest cover and numerous wetlands in the headwaters of the Clyburn River Aquifer have resulted in nutrients characterized by non-detectable to low concentrations of nitrogen as nitrite + nitrate (as N) $(<0.05$ to $0.16 \mathrm{mg} / \mathrm{L}$ ). 
(a)

(b)
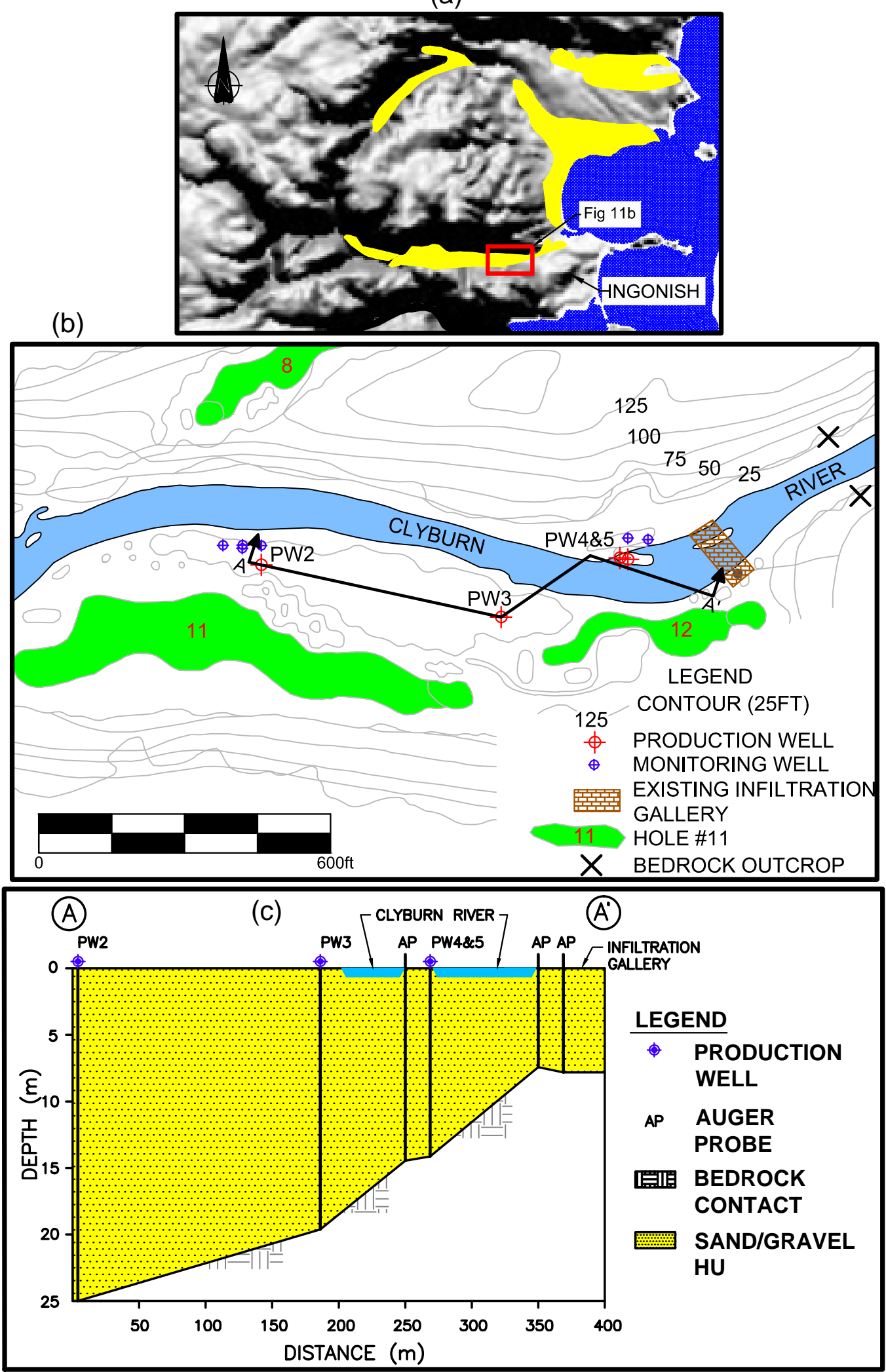

Figure 11. Location, mapped aerial extent $(\mathrm{a}, \mathrm{b})$, and vertical configuration (c) of the Clyburn River BBV aquifer at Ingonish, as summarized from various sources. 


\section{MANAGEMENT ISSUES}

The need for managing BBV aquifers on Cape Breton Island is strengthened by the variety of ways they are presently utilized. They provide potable groundwater supplies for five municipal and three commercial/industrial ventures, as well as irrigation for four golf courses. They can be critical as surficial aquifers for domestic supplies in areas underlain by evaporite bedrock aquifers with poor water quality. They are critical in supporting salmonids and other fresh water, estuarine and possible near shore, coastal ecosystems. The design, monitoring, and remedial strategies for three waste disposal sites has been influenced by their presence, as has geotechnical designs for 21 bridge structures and dewatering control for four large construction sites on the Island. One BBV aquifer has, for the most part, already been removed to supply construction aggregate. These aquifers do not necessarily follow underfit surface streams and can divert groundwater flow under surface watershed divides. Depending upon the impact of changing climate the large storage capacity and permeability of these aquifers may play a critical future role in developing adaptation strategies for groundwater withdrawals, protecting fresh water aquatic ecosystems, as well as providing emergency response to natural disasters.

Low frequency, manual monitoring at two sites on Cape Breton Island indicates no notable changes in head levels or select indicator chemistry over the past 17 years (Glen Brook Aquifer) and 27 years (Broad Cove Aquifer). This suggests that these sites remain unaffected to date by historical land use, acid rain, and changing climate. Impacts from basemetal mineralization, radon gas, and natural oil/gas have not been detected within the three case study aquifers.

To support effective management of these BBV aquifers on Cape Breton Island, interdisciplinary research should incorporate six issues:

(1) The focus of research should be on characterizing hydrogeological conditions within BBV aquifers in areas of enhanced land use, existing large groundwater withdrawals, and/or important aquatic ecosystems. This will aid in managing the aquifer for diverse uses such as water supply, aggregate extraction, and/or supporting river, estuarine, and near-shore coastal ecosystems.

(2) Understanding the influence of channel-aquifer interactions in supporting benthic invertebrates, salmonids, sediment transport, channel morphology, and hyporheic zones would aid in developing effective groundwater withdrawal permitting.

(3) There is a need to understand the impacts of changing climate on groundwater levels within the BBV aquifers of Cape Breton Island. Any notable water table declines could have resultant impacts on creating ephemeral reaches within surface channels and may alter the presence and persistence of vernal pools and wetlands, with subsequent impacts on aquatic ecosystems.

(4) The unconsolidated nature of the aquifer materials which form the surface channel allows for active meandering. This constantly modifies the aquifer, alters riparian forest cover, provides good habitat for salmonids and beavers, and alters the extent of floodplains and vernal pools. A more comprehensive understanding of these issues will aid in positioning groundwater extraction points, developing channel erosion control procedures, identifying groundwater under direct influence (GUDI) situations, and developing well head protection strategies.

(5) Five of the present municipal water supplies have wells within 0.5 to $2.7 \mathrm{~km}$ of brackish to saline waters along the coast, with wells bottomed approximately 5 and $15 \mathrm{~m}$ below sea level. A means of monitoring the impact of pumping on the saltwater lens, especially given predicted sea-level rise scenarios, should be developed.

(6) The provincial groundwater observation well monitoring program should be integrated and enhanced with wells positioned within select BBV aquifers, in proximity to surface water flow gauging stations.

\section{CONCLUSIONS}

Cape Breton Island provides a hydrogeological view into a tectonically ancient, exhumed, glaciated, now tectonically inactive, deep crustal terrain, with BBV aquifers comprised of Cretaceous, Pleistocene, and Holocene deposits. Buried bedrock valley aquifers were found at 92 (61\%) of 150 sites studied on the island. Of these $28 \%$ were "proven", $24 \%$ were "probable" and 9\% "possible". Their architecture is varied, including: (1) sand-dominated, localized, narrow, subglacial channels carved into sedimentary bedrock and semi-confined by and interbedded with tills; (2) broad, sand- and/or gravel-dominated alluvial valley deposits covering incised bedrock channels at depth; and (3) ice contact features buried at depth within thick lacustrine clay and till deposits.

The BBV aquifers presented in this paper generally exhibit intermediate to very high transmissivities, relatively large safe yields, and potable water chemistry. The water quality in deeper portions of the aquifers is controlled by the underlying bedrock, which in localized areas can be influenced by underlying evaporite rocks. No notable metal mineralization, radon gas, and natural oil/gas has been found to date within the aquifers studied. These characteristics have allowed seven aquifers to provide potable water for eight municipal, industrial, and commercial purposes for between 13 and 50 years.

All physical and chemical data on the 150 sites investigated have been provided to the Nova Scotia Department of Natural Resources for inclusion in their digital water resources data base; to be made public at their discretion. 
Future research is required to identify and characterize these aquifers in select high priority areas. These include areas experiencing enhanced pumping, altered land use (e.g. suburbanization, agriculture and forestry), and/or aggregate extraction, as well as those with rivers important to aquatic ecosystems. This approach is especially relevant considering potential impacts arising from changing climate and rising sea level.

\section{ACKNOWLEDGEMENTS}

The discussion provided in this paper evolves from the author's experience and that of Lynn Baechler on Cape Breton Island over the last 40 years. Numerous discussions over the years with Dr. D. Grant, Dr. John Shaw and Dr. R. Stea proved greatly beneficial in understanding the geological base for this assessment. Appreciation is extended to the Nova Scotia Department of Natural Resource's library staff for their diligent help in locating historical geological data, and use of their water-well data base. Appreciation is also extended to the Nova Scotia Department of Transportation and Infrastructural Renewal for geotechnical reports on bridge structures, as well as Georgia Pacific Canada LP and Parks Canada for their relevant documents. The paper was significantly improved by comments from anonymous reviewers and the editor Dr. Chantel Nixon. The author would like to gratefully acknowledge and thank all those that assisted in this endeavor. Messrs. Neil Bach, Cory Youden and Bill Jones of Exp Services Inc. are greatly acknowledged for aid in drafting the figures and developing the associated GIS data base which facilitated the analysis.

\section{REFERENCES}

ADI Ltd. 1999. Registration of undertaking for environmental assessment for a proposed gypsum mine, Melford, Cape Breton Nova Scotia. Unpublished report submitted to Georgia Pacific Canada Inc. 119 p.

ADI Ltd. 2000. Geotechnical report truck dump \#1. Unpublished report submitted to Georgia Pacific Canada Inc. $24 \mathrm{p}$.

ADI Ltd. 2001. Melford gypsum mine water supply. Unpublished report submitted to Georgia Pacific Canada Inc. $17 \mathrm{p}$.

ADI Ltd. 2002a. The Community of Inverness water system: development of production well No. 2. Unpublished report submitted to the Municipality of the County of Inverness. $15 \mathrm{p}$.

ADI Ltd. 2002b. Kenloch landfill 2001 annual groundwater monitoring report. Unpublished report submitted to Municipality of the County of Inverness. $17 \mathrm{p}$.

ADI Ltd. 2005. Final report on geotechnical investigations for Cabot Trail and Keltic Lodge access road rehabilitation study, Ingonish Beach, Nova Scotia. Unpublished report submitted to O'Halloran Campbell Cons. Ltd. 19 p.

ADI Ltd. May 2000. Glen Brook salmonid management plan. Unpublished report submitted to Georgia Pacific Canada Inc. 52 p.

ADI Nolan Davis Ltd. 1993. Clyburn River: study of coastal and fluvial processes. Unpublished report submitted to Cape Breton Highlands National Park. 73 p.

Atkinson, N., Andriashek, L.D., and Slattery, S.R. 2013. Morphological analysis and evolution of buried tunnel valleys in northeast Alberta, Canada. Quaternary Science Reviews, 65, pp. 53-72. https://doi.org/10.1016/j. quascirev.2012.11.031

Baechler F. 1979. A hydrological assessment of the Kenloch waste disposal site, Inverness County, Cape Breton, Nova Scotia. Unpublished internal report, Nova Scotia Department of Environment. 83 p.

Baechler F. 1980. Pump testing program Department of Lands and Forests Strathlorne Nursery, Inverness County. Unpublished internal correspondence, Nova Scotia Department of Environment. $4 \mathrm{p}$.

Baechler, F. 2015. The geology and hydrogeology of faults on Cape Breton Island, Nova Scotia, Canada: an overview. Atlantic Geology, 51, pp. 242-268. https://doi. org/10.4138/atlgeol.2015.010

Baechler, F. and Baechler, L. 2009. Mapping Cape Breton's Waterscape - Approach and Challenges. In International Association of Hydrogeologists, Canadian National Chapter GeoHalifax conference, $7 \mathrm{p}$.

Baechler F. and Boehner, R. 2014. Geology and hydrogeology of karst in Cape Breton: an overview. Canadian Journal of Earth Sciences, 51, pp. 1-14. https://doi.org/10.1139/cjes2013-0157

Beaney, C.L. and Shaw, J. 2000. The subglacial geomorphology of southeast Alberta: evidence for subglacial meltwater erosion. Canadian Journal of Earth Sciences, 37, pp. 5161. https://doi.org/10.1139/e99-112

Boulton, G.S., Lunn, R., Vidstrand, P, and Zatsepin, S. 2007. Subglacial drainage by groundwater-channel coupling and the origin of esker systems: Part 1-glaciological observations. Quaternary Science Reviews, 26, pp. 10671090. https://doi.org/10.1016/j.quascirev.2007.01.007

Boulton, G.S., Hagdorn, M., Maillot, P.B., and Zatsepin, S. 2009. Drainage beneath ice sheets: groundwater-channel coupling and the origin of esker systems from former ice sheets. Quaternary Science Reviews, 28, pp. 621-638. https://doi.org/10.1016/j.quascirev.2008.05.009

Brennand, R.A. and Shaw, J. 1994. Tunnel channels and associated landforms, south-central Ontario: their implications for ice-sheet hydrology. Canadian Journal of Earth Sciences, 31, pp. 505-522. https://doi.org/10.1139/ e94-045

Bredehoeft, J. 2005. The conceptualization model problemsurprise. Hydrogeology Journal, 13, pp. 37-46. https:// doi.org/10.1007/s10040-004-0430-5

Broster, B.E. and Pupek, D.A. 2001. The significance of 
buried landscape in subsurface migration of dense nonaqueous phase liquids: The case of perchloroethylene in the Sussex Aquifer, New Brunswick. Environmental and Engineering Geoscience, VII, pp. 17-29. https://doi. org/10.2113/gseegeosci.7.1.17

Butler, K.E., Nadeau, J.C., Parrott, R., and Daigle, A. 2004. Delineating recharge to a river valley aquifer by riverine seismic and EM methods. Journal of Environmental and Engineering Geophysics, 9, pp. 95-109. https://doi. org/10.4133/JEEG9.2.95

CBCL Ltd. 1995a. Aquifer yield assessment Clyburn Brook, Ingonish, Cape Breton. Unpublished report submitted to Public Works Canada, Parks Division. 25 p.

CBCL Ltd. 1995b. Monitor well installation infiltration gallery, Clyburn Brook. Unpublished report submitted to Public Works Canada Parks Division. 8 p.

CBCL Ltd. 1996. Ingonish water supply wells construction report. Unpublished report submitted to Public Works Canada Parks Division. 12 p.

Cole, J., Coniglio, M., and Gautrey, S. 2009. The role of buried bedrock valleys on the development of karstic aquifers in flat-lying carbonate bedrock; insights from Guelph, Ontario, Canada. Hydrogeology Journal, 17, pp. 1411-1425. https://doi.org/10.1007/s10040-009-0441-3

Creyts, T.T. and Schoof, C.G. 2009. Drainage through subglacial water sheets. Journal of Geophysical Research, $114,18 \mathrm{p}$.

Cummings, D. I., Russell, H.A.J., and Sharpe, D.R. 2012. Buried-valley aquifers in the Canadian Prairies: geology, hydrogeology, and origin. Canadian Journal of Earth Sciences, 49, pp. 987-1004. https://doi.org/10.1139/ e2012-041

Denne, J.E., Yarger, H.L., Macfarlane, P.A., Knapp, R.W., Sophocleous, J.A., Lucas, J.R., and Steeples, D.W. 1984. Remote sensing and geophysical investigations of glacial buried valleys in northeastern Kansas, Groundwater, 22, pp. 56-65. https://doi.org/10.1111/j.1745-6584.1984. tb01476.x

Exp Services Inc. 2014. Kenloch Landfill 2013 annual groundwater monitoring report Inverness County waste management facility. Unpublished report submitted to the Municipality of the County of Inverness. $16 \mathrm{p}$.

Exp. Services Inc. 2017. Kenloch Landfill 2016 annual groundwater monitoring report Inverness County waste management facility. Unpublished report submitted to the Municipality of the County of Inverness. $16 \mathrm{p}$.

Falcon-Lang, H.J., Fensome, R.A., Gibling, M.R., Malcolm, J., Fletcher, K.R., and Molleman, M. 2007. Karst-related outliers of the Cretaceous Chaswood Formation of Maritime Canada. Canadian Journal of Earth Sciences, 44, pp. 619-642. https://doi.org/10.1139/e06-119

Faunt, C.C., Belitz, K., and Hanson, R.T. 2010. Development of a three-dimensional model of sedimentary texture in valley-fill deposits of Central Valley, California, USA. Hydrogeology Journal, 18, pp. 625-649. https://doi. org/10.1007/s10040-009-0539-7
Flint, J.J. and Lolcama, J. 1986. Buried ancestral drainage between Lakes Erie and Ontario. Geological Society of America Bulletin, 97, pp. 75-84. https://doi. org/10.1130/0016-7606(1986)97<75:BADBLE >2.0.CO;2

Gao, C. 2011. Buried bedrock valleys and glacial and subglacial meltwater erosion in southern Ontario, Canada. Canadian Journal of Earth Sciences, 48, pp. 801818. https://doi.org/10.1139/e10-104

Grant, D.R. 1994. Quaternary Geology, Cape Breton Island, Nova Scotia. Geological Survey of Canada Bulletin 482. 159 p. https://doi.org/10.4095/194812

Grasby, S.E., Betcher, R.N., Maathuis, H., and Wozniak, P.R.J. 2014. Chapter 10 Plains Region. In Canada's Groundwater Resources. Edited by A. Rivera. Fitzhernry and Whiteside, Markham Ontario, pp. 359-413.

Gray, H.H. 2001. Subglacial meltwater channels (Nye channels or N-channels) in sandstone at Hindostan Falls, Martin County Indiana. Proceedings of the Indiana Academy of Science, 110, pp 1-8.

Henley, M., Ferguson, G., and Baechler, F. 2009. Quantifying groundwater discharge at various spatial and temporal scales. In International Association of Hydrogeologists GeoHalifax conference. pp. 1255-1261.

Hickin, A.S., Kerr, B., Turner, D.G., and Barchyn, T.E. 2008. Mapping Quaternary paleovalleys and drift thickness using petrophysical logs, northeast British Columbia, Fontas map sheet, NTS 941. Canadian Journal of Earth Sciences, 45, pp. 577-591. https://doi.org/10.1139/e07063

Hill, M.C. 2006. The practical use of simplicity in developing ground water models. Groundwater, 44, pp. 775-781. https://doi.org/10.1111/j.1745-6584.2006.00227.x

Holysh, S. and Gerber, R. 2014. Groundwater knowledge management for southern Ontario: an example from the Oak Ridges Moraine. Canadian Water Resources Journal, 39, pp. 240-253. https://doi.org/10.1080/07011784.2014. 914788

Kehew, A.E. and Boettger, W.M. 1986. Depositional environments of buried-valley aquifers in North Dakota. Ground Water, 24, pp. 728-734. https://doi. org/10.1111/j.1745-6584.1986.tb01688.x

Kehew, A.E., Piotrowski, J.A., and Jergensen, F. 2012. Tunnel valleys: concepts and controversies-a review. Earth Science Reviews, 113, pp.33-58. https://doi.org/10.1016/j. earscirev.2012.02.002

Kennedy, G.W. 2014. Identification and preliminary mapping of surficial aquifers in Nova Scotia. In Mineral Resources Branch, Report of Activities 2013. Nova Scotia Department of Natural Resources, Report ME2014-001, pp. 33-43.

King C.A.M. 1980. Thresholds in Glacial Geomorphology. In Thresholds in Geomorphology, Edited by D.R. Coates and J.D. Vitek. Dowden and Culver Inc., pp 297-321.

Kor, P.S.G., Shaw, J., and Sharpe, D.R. 1991. Erosion of bedrock by subglacial meltwater, Georgian Bay, Ontario: 
a regional view. Canadian Journal of Earth Sciences, 28, pp. 623-642. https://doi.org/10.1139/e91-054

Krasny, J. 1993. Classification of transmissivity magnitude and variation. Ground Water, 31, pp. 230-236. https://doi. org/10.1111/j.1745-6584.1993.tb01815.x

LeGrand, H.E. and Rosen, L. 2000. Systematic Makings of Early Stage Hydrogeologic Conceptual Models. Groundwater, 38, pp. 887-893. https://doi. org/10.1111/j.1745-6584.2000.tb00688.x

Lemieux, J.M., Sudicky, E.A., Peltier, W.R., and Tarasov, L. 2008. Dynamics of groundwater recharge and seepage over the Canadian landscape during the Wisconsinian glaciation. Journal of Geophysical Research, 113, 18 p.

MacRae, R.A. and Christians, A.R. 2013. A re-examination of Pleistocene tunnel valley distribution the central Scotia Shelf. Canadian Journal of Earth Sciences, 50, pp. 535544. https://doi.org/10.1139/cjes-2012-0057

Mayo, A.L., Morris, T.H., Peltier, S., Petersen, E.C., Payne, K., Holman, L.S., Tingey, D., Fogel, R., Black, B.J., and Biggs, T.D. 2003. Active and inactive groundwater flow systems: evidence from a stratified, mountainous terrain. Geological Society of America Bulletin, 115, pp. 14561472. https://doi.org/10.1130/B25145.1

McMahon, P., Short, G., and Walker, D. 1986. Petroleum wells and drill holes with petroleum significance onshore Nova Scotia. Nova Scotia Department Mines and Energy, Information Series No 10. $194 \mathrm{p}$.

Meyer, P.A. and Eyles, C.H. 2007. Nature and origin of sediments infilling poorly defined buried bedrock valleys adjacent to the Niagara Escarpment, southern Ontario, Canada. Canadian Journal of Earth Sciences, 44, pp. 89105. https://doi.org/10.1139/e06-085

Morgan. A., Paulen, J.R.C., and Froese, C.R. 2008. Ancestral buried valleys of the Peace River: Effects on the town of Peace River. In GeoEdmonton 2008 conference, pp. 1219-1226.

Newbury Hydraulics. 2011. Clyburn River study 2011 Highland Links Reach, Lower Clyburn River Infrastructure Stabilization Project, Cape Breton National Park. Unpublished report submitted to Parks Canada. 22 p.

Nolan Davis and Assoc. Ltd. 1990. Kenloch landfill: expansion of the groundwater monitoring program, 1988. Unpublished report submitted to the Municipality of the County of Inverness. 27 p.

Nova Scotia Museum. 1997. Natural history of Nova Scotia, I; topics and habitats. Co-published by Province of Nova Scotia and Nimbus Publishing. 304 p.

Pascucci, V., Gibling, M.R., and Williamson, M.A. 2000. Late Paleozoic to Cenozoic history of the offshore Sydney Basin, Atlantic Canada. Canadian Journal of Earth Sciences, 37, pp. 1143-1165. https://doi.org/10.1139/e00028

Person, M., McIntosh, J., Bense, V., and Remenda, V.H.
2007. Pleistocene hydrology of North America: The role of ice sheets in reorganizing groundwater flow systems. Reviews of Geophysics, 45, 28 p.

Pinder G.F. 1966. Report on the groundwater survey, Inverness, Nova Scotia. Unpublished internal report, Nova Scotia Department of Mines. 9 p.

Pugin, A.J.M., Oldenborger, G.A., Cummings, D.I., Russell, H.A.J., and Sharpe, D.R. 2014. Architecture of buried valleys in glaciated Canadian Prairie regions based on high resolution geophysical data. Quaternary Science Reviews, 86, pp. 13-23. https://doi.org/10.1016/j. quascirev.2013.12.007

Rampton, V.N. 2000. Large-scale effects of subglacial meltwater flow in the southern Slave Province, Northwest Territories, Canadian Journal of Earth Sciences, 37, pp. 81-93. https://doi.org/10.1139/e99-110

Randall, A.D., Francis, R.M., Frimpter, M.H., and Emery, J.M. 1988. Region 19, Northeastern Appalachians. In Hydrogeology. Edited by W. Back, J.S. Rosenshein and P.R. Seaber. The Geology of North America, 0-2, Geological Society of America, pp. 177-186.

Rivard, C., Michaud, Y., Deblonde, C., Boisvert, V., Carrier, C., Morin, R.H., Calvert, T., Vigneault, H., Conohan, D., Castonguay, S., Lefebvre, R., Rivera, A., and Parent, M. 2008. Canadian Groundwater Inventory: Regional hydrogeological characterization of the south-central part of the Maritimes Basin. Geological Survey of Canada Bulletin 589. 86 p. https://doi.org/10.4095/223958

Rosgen, D. and Silvey, L. 1998. Field Guide for Stream Classification. Wildland Hydrology. 193 p.

Russell, H.A.J., Sharpe, D.R., Logan, C., and Brennand, T.A. 2001. Not without sedimentology: Building groundwater studies in the Oak Ridges Moraine, southern Ontario. In Geological Models for Groundwater Flow Modeling, 35 Annual Meeting, North-Central Section, Geological Society of America, 22 April 2001. Edited by R.C. Berg and L.H. Thorleifson., Illinois State Geological Survey, open File Series 2001-1, pp. 38-41.

Russell, H.A.J., Hinton, M., van der Kamp, G., and Sharpe, D.R. 2004. An overview of the architecture, sedimentology and hydrogeology of buried-valley aquifers in Canada. In Proceedings of the $57^{\text {th }}$ Canadian Geotechnical Conference and the $5^{\text {th }}$ joint CGS-IAH Conference, pp. 26-33. https://doi.org/10.4095/215602

Savard, M., Martel, R., Nastev, M., Sharpe, D.R., Boisvert, E., and Parent, M. 2014. Chapter 3 An approach to regional assessments of groundwater resources. In Canada's Groundwater Resources. Edited by A. Rivera. Fitzhenry and Whiteside, Markham Ontario, pp. 62-98.

Seyoum, W.M. and Eckstein, Y. 2014. Hydraulic relationships between buried valley sediments of the glacial drift and adjacent bedrock formation in northeastern Ohio, USA. Hydrogeology Journal, 22, pp.1193-1206. https://doi. org/10.1007/s10040-014-1128-y 
Sharpe, D.R., Russell, H.A.J., Dyke, L., Grasby, S.E., Gleeson, T., Michaud, Y., Savard, M.M., Wei, M., and Wozniak, P.R.J. 2014. Hydrogeological Regions of Canada. In Canada's Groundwater Resources. Edited by A. Rivera. Fitzhenry and Whiteside, Markham Ontario, pp. 264-299.

Sharpe Jr., J.M. 1988. Alluvial aquifers along major rivers. In Hydrogeology. Edited by W. Back, J.S. Rosenshein, and P.R. Seaber. The Geology of North America, Geological Society of America, 0-2, Chapter 33, pp. 273-282. https:// doi.org/10.1130/DNAG-GNA-O2.273

Shaver, R.B. and Pusc, S.W. 1992. Hydraulic barriers in Pleistocene buried-valley aquifers. Ground Water, 30, pp. 21-28. https://doi.org/10.1111/j.1745-6584.1992. tb00807.x

Shaw, J. 2005. Geomorphic evidence of postglacial terrestrial environments on Atlantic Canadian Continental Shelves, Geographie Physique et Quaternaire, 59, pp. 141-154. https://doi.org/10.7202/014752ar

Shaw, J., Gareau, P., and Courtney, R.C.2002.Palaeogeography of Atlantic Canada 13-0 kyr. Quaternary Science Reviews, 21, pp. 1861-1878. https://doi.org/10.1016/S0277-3791 (02)00004-5

Shaw, J., Taylor, R.B., Patton, E., Potter, D.P., Parkes, G.S., and Hayward, S. 2006. The Bras d' Or Lakes, Nova Scotia: seafloor topography, backscatter strength, coastline classification, and sensitivity of coasts to sea-level rise. Geological Survey of Canada Open File 5397. 99 p. https://doi.org/10.4095/223022

Shaw, J., Todd, B.J., Brushett, D., Parrott, D.R., and Bell, T. 2009. Late Wisconsinan glacial land-systems on Atlantic Canadian shelves: new evidence from multibeam and single-beam sonar data. Boreas, 38, pp. 146-159. https:// doi.org/10.1111/j.1502-3885.2008.00043.x

SNC Lavelin. 2015. Clyburn Brook bridge replacementRS3 design development report. Unpublished report submitted to Public Works and Government Services Canada. $8 \mathrm{p}$.

Springer, A.E. and Bair, E.S. 1992. Comparison of methods used to delineate capture zones of wells: stratified-drift buried-valley aquifer. Groundwater, 30, pp. 908-917. https://doi.org/10.1111/j.1745-6584.1992.tb01574.x

Standford, J.A. and Ward, J.V. 1993. An ecosystem perspective of alluvial rivers: connectivity and the hyporheic corridor. Journal North American Benthological Society, 12, pp. 48-60. https://doi.org/10.2307/1467685

Stea, R.R. and Pullan, S.E. 2001. Hidden Cretaceous basins in Nova Scotia. Canadian Journal of Earth Sciences, 38, pp. 1335-1354. https://doi.org/10.1139/e01-023

Stea, R.R., Pullan, S.E., and Feetham, M. 2003. MesozoicCenozoic stratigraphy of the lowlands of southwest Cape Breton Island (NTS 11F/11, 11F/14). In Mineral Resources Branch, Report of Activities 2002. Nova Scotia Department of Natural Resources Report 2003-1, pp. 103-126.
Stea, R.R., Piper, D.J.W., Fader, D.B.J., and Boyd, R. 1998. Wisconsinan glacial and sea-level history of Maritime Canada and the adjacent continental shelf: a correlation of land and sea events. Geological Society of America Bulletin, 110, pp. 821-845. https://doi.org/10.1130/00167606(1998) $110<0821$ :WGASLH $>2.3 . C O ; 2$

Stea, R.R., Feetham, M., Pullan, S.E., Ostrom, W., Baechler, L., and Ryan, R.J. 2006. Geology and economic potential of the glacial clay and sand deposits of Inverness County, southwest Cape Breton Island. Economic Geology Series ME 2006-1. In Mineral Resources Branch, Nova Scotia Department Natural Resources. 110 p.

Tawil, A.H. and Harriman, F.B. 2001. Aquifer performance under the Mactaquac Dam. In Canadian Dam Association Annual Conference 2001, Fredericton, New Brunswich, $11 \mathrm{p}$.

Thornthwaite, C. 1948. An approach towards a rational classification of climate. Geographical Review, 38, pp. 55-94. https://doi.org/10.2307/210739

Toth, J. 1962. A theoretical analysis of groundwater flow in small drainage basins. In Proceedings of Hydrogeology, Symposium N. 3 - Groundwater National Research Council of Canada, Association Committee Geodesy and Geophysics, pp. 81-90.

Upson, J. E. and Spencer, C.W. 1964. Bedrock valleys of the New England coast as related to fluctuations of sea level. United States Geological Survey Professional Paper 454$\mathrm{M}, 44 \mathrm{p}$.

Van der Kamp, G. and Maathuis, H. 2012. The unusual and large drawdown response of buried-valley aquifers to pumping. Groundwater, 50, pp. 207-215. https://doi. org/10.1111/j.1745-6584.2011.00833.x

Van der Vegt, P., Janszen, A., and Moscariello, A. 2012. Tunnel valleys: current knowledge and future perspectives. In Glaciogenic Reservoirs and Hydrocarbon Systems. Edited by M. Huuse, J. Redfern, D.P. Le Heron, R.J Dixon, A. Moscariello, and J. Craig. Geological Society of London, Special Publications 368. 23 p. https://doi.org/10.1144/ SP368.13

Wei, M., Ronneseth, K., Allen, D.M., Kohut, A.P., Grasby, S.E., and Turner, B. 2014. Cordilleran Hydrogeological Region. In Canada's Groundwater Resources. Edited by A. Rivera. Fitzhenry and Whiteside, Markham Ontario, pp. 264-299.

Weissmann, G.S., Zhang, Y., Fogg, G.R., and Mount, J.F. 2004. Influence of incised-valley-fill deposits on hydrogeology of a stream-dominated alluvial fan. In Aquifer Characterization. Edited by J.W. Bridge and D.W. Hyndman. SEPM Society for Sedimentary Geology Special Publication 80, pp 15-28. https://doi.org/10.2110/ pec.04.80.0015

Editorial responsibility: Chantel Nixon 